\title{
The relative importance of phytoplankton aggregates and zooplankton fecal pellets to carbon export: insights from free-drifting sediment trap deployments in naturally iron-fertilised waters near the Kerguelen Plateau
}

\author{
E. C. Laurenceau-Cornec ${ }^{1,2}$, T. W. Trull ${ }^{2,3}$, D. M. Davies ${ }^{2}$, S. G. Bray ${ }^{2}$, J. Doran ${ }^{4}$, F. Planchon ${ }^{5}$, F. Carlotti ${ }^{6}$, \\ M.-P. Jouandet ${ }^{6}$, A.-J. Cavagna ${ }^{7}$, A. M. Waite ${ }^{4,8}$, and S. Blain ${ }^{9,10}$ \\ ${ }^{1}$ CSIRO-UTAS Quantitative Marine Sciences PhD Program, Institute for Marine and Antarctic Studies, \\ University of Tasmania, Private Bag 129, Hobart TAS 7001, Australia \\ ${ }^{2}$ Antarctic Climate and Ecosystems Cooperative Research Centre, University of Tasmania, Private Bag 80, Hobart TAS 7001, \\ Australia \\ ${ }^{3}$ Commonwealth Scientific and Industrial Research Organisation, Marine and Atmospheric Research, Castray Esplanade, \\ Hobart TAS 7000, Australia \\ ${ }^{4}$ UWA Oceans Institute, The University of Western Australia (M470), 35 Stirling Highway, Crawley WA 6009, Australia \\ ${ }^{5}$ Laboratoire des Sciences de l'Environnement Marin (LEMAR), Université de Brest, CNRS, IRD, UMR6539, IUEM, \\ Technopôle Brest Iroise, Place Nicolas Copernic, 29280 Plouzané, France \\ ${ }^{6}$ Mediterranean Institute of Oceanography (MIO), Aix-Marseille Université, CNRS-IRD, 13288 Marseille, CEDEX 09, \\ France \\ ${ }^{7}$ Vrije Universiteit Brussel, Analytical and Environmental Geochemistry Dept., Brussels, Belgium \\ ${ }^{8}$ Alfred Wegener Institute Helmholz Centre for Polar and Marine Research, Building E-2155, Am Handelshafen 12, \\ 27570 Bremerhaven, Germany \\ ${ }^{9}$ Sorbonne Universités, UPMC Univ. Paris 06, UMR 7621, Laboratoire d'Océanographie Microbienne, \\ Observatoire Océanologique, 66650 Banyuls/mer, France \\ ${ }^{10}$ CNRS, UMR 7621, Laboratoire d'Océanographie Microbienne, Observatoire Océanologique, 66650 Banyuls/mer, France
}

Correspondence to: E. C. Laurenceau-Cornec (emmanuel.laurenceau@utas.edu.au)

Received: 18 August 2014 - Published in Biogeosciences Discuss.: 19 September 2014

Revised: 16 December 2014 - Accepted: 5 January 2015 - Published: 17 February 2015

\begin{abstract}
The first KErguelen Ocean and Plateau compared Study (KEOPS1), conducted in the naturally iron-fertilised Kerguelen bloom, demonstrated that fecal material was the main pathway for exporting carbon to the deep ocean during summer (January-February 2005), suggesting a limited role of direct export via phytodetrital aggregates. The KEOPS2 project reinvestigated this issue during the spring bloom initiation (October-November 2011), when zooplankton communities may exert limited grazing pressure, and further explored the link between carbon flux, export efficiency and dominant sinking particles depending upon surface plankton community structure. Sinking particles were collected in polyacrylamide gel-filled and standard free-drifting sed-
\end{abstract}

iment traps (PPS3/3), deployed at six stations between 100 and $400 \mathrm{~m}$, to examine flux composition, particle origin and their size distributions. Results revealed an important contribution of phytodetrital aggregates $(49 \pm 10$ and $45 \pm 22 \%$ of the total number and volume of particles respectively, all stations and depths averaged). This high contribution dropped when converted to carbon content $(30 \pm 16 \%$ of total carbon, all stations and depths averaged), with cylindrical fecal pellets then representing the dominant fraction $(56 \pm 19 \%)$.

At 100 and $200 \mathrm{~m}$ depth, iron- and biomass-enriched sites exhibited the highest carbon fluxes (maxima of 180 and $84 \pm$ $27 \mathrm{mg} \mathrm{Cm}^{-2} \mathrm{~d}^{-1}$, based on gel and PPS3/3 trap collection respectively), especially where large fecal pellets dominated 
over phytodetrital aggregates. Below these depths, carbon fluxes decreased $(48 \pm 21 \%$ decrease on average between 200 and $400 \mathrm{~m}$ ), and mixed aggregates composed of phytodetritus and fecal matter dominated, suggesting an important role played by physical aggregation in deep carbon export.

Export efficiencies determined from gels, PPS3/3 traps and ${ }^{234} \mathrm{Th}$ disequilibria (200 $\mathrm{m}$ carbon flux/net primary productivity) were negatively correlated to net primary productivity with observed decreases from $\sim 0.2$ at low-iron sites to $\sim 0.02$ at high-iron sites. Varying phytoplankton communities and grazing pressure appear to explain this negative relationship. Our work emphasises the need to consider detailed plankton communities to accurately identify the controls on carbon export efficiency, which appear to include small spatio-temporal variations in ecosystem structure.

\section{Introduction}

Physical and biological processes occurring in the surface ocean generate a vast diversity of particles. These particles represent potential vehicles to export organic carbon to the deep ocean, where a small fraction can eventually be sequestered in the sediments. This process, known as the "biological carbon pump" (BCP), influences the level of atmospheric carbon dioxide and thus the global climate system (Volk and Hoffert, 1985; Lam et al., 2011).

Primary production in the euphotic layer builds a stock of phytoplankton cells. If their concentration and stickiness are high enough (Jackson, 1990), these cells can collide, attach and form large phytodetrital aggregates (Burd and Jackson, 2009; McCave, 1984), with those reaching sizes greater than $0.5 \mathrm{~mm}$ known as "marine snow" (Alldredge and Silver, 1988). Alternatively, phytoplankton cells can be tightly packed into dense fecal pellets through zooplankton grazing (Silver and Gowing, 1991). Because of their large size and high density respectively, phytodetrital aggregates and fecal pellets are major constituents of the downward flux, and several studies have found either fecal pellets (Fowler and Knauer, 1986; Pilskaln and Honjo, 1987; Bishop et al., 1977; Wassmann et al., 2000; Ebersbach and Trull, 2008; Cavagna et al., 2013) or large organic aggregates (Turner, 2002; Alldredge and Gotschalk, 1989; De La Rocha and Passow, 2007; Jackson, 1990; Burd and Jackson, 2009) to be the dominant vectors of carbon to depth.

Because grazing causes losses of organic carbon by respiration (Michaels and Silver, 1988; Alldredge and Jackson, 1995), direct export via the sinking of phytodetrital aggregates represents the most efficient operating mode of the BCP. However, the ecosystem structure and environmental conditions under which primary production can be exported directly via phytodetrital aggregates are still unclear, and their determination would considerably improve the predictions of the efficiency of the $\mathrm{BCP}$ in varying conditions.
The volume fraction of phytodetrital aggregates vs. fecal pellets in the total flux and their volume-to-carbon-content ratio select the dominant carbon export mode; these relative contributions depend on numerous parameters, including primary productivity, biomass, interactions between primary producers and heterotrophic communities (Michaels and Silver, 1988), physical fragmentation, microbial decomposition, coprophagy and the velocity at which particles settle (Turner, 2002).

The Southern Ocean contains the largest high-nutrient, low-chlorophyll (HNLC) area of the world ocean and is an essential player in global biogeochemistry (Sigman and Boyle, 2000). In these waters, abundant macronutrients (silicic acid, nitrate and phosphate) can fuel primary production given available light and sufficient iron, a limiting micronutrient (de Baar et al., 1995; Martin, 1990). The Kerguelen Plateau offers the opportunity to study the functioning of the BCP in a naturally iron-fertilised region (Blain et al., 2007). The first KErguelen Ocean and Plateau compared Study (KEOPS1), demonstrated that most of the sinking flux collected in polyacrylamide gel sediment traps was derived from copepod fecal detritus (intact or degrading pellets and fecal material reaggregated with phytodetritus, hereafter called "fecal aggregates"), and reported limited evidence for phytodetrital aggregates formed by direct flocculation of phytoplankton cells (Ebersbach and Trull, 2008). Number and volume fluxes were dominated by aggregates but represented a small fraction of the total carbon flux, owing to their low volume-to-carbon-content ratio. Several natural and artificial iron-fertilisation experiments conducted at the same time of the year but in different locations in the Southern Ocean (e.g. SAZ-Sense study and SOFeX) displayed similar export modes relying mainly on fecal matter (Bowie et al., 2011; Ebersbach et al., 2011; Coale et al., 2004; Lam and Bishop, 2007). In contrast, other artificial and natural iron experiments (SOIREE, CROZEX and EiFeX) have demonstrated a direct export via the sinking of phytodetrital aggregates or single phytoplankton cells (Boyd et al., 2000; Waite and Nodder, 2001; Pollard et al., 2007; Salter et al., 2007; Smetacek et al., 2012).

These variations among studies may reflect the timevarying aspects of export. In his review of Southern Ocean ecosystem contribution to carbon export, Quéguiner (2013) suggests that from the onset of a bloom to its decline and subsequent export event, phytoplankton, and to a lesser extent zooplankton communities, is subject to several rapid successions. The complexity of the processes is also reflected by the past 30 years of empirical and modelling studies attempting to relate deep carbon export variations to surface productivity (Eppley and Peterson, 1979; Suess, 1980; Wassmann, 1990; Guidi et al., 2009). In general, the ratio between export and production in the surface ocean is low $(<5-10 \%$; Buesseler, 1998), but decoupling associated with high-export events (e.g. high-latitude blooms), or even negative relationships, has been noted (Maiti et al., 2013; Buesseler, 1998; 
Ebersbach et al., 2011; Lam and Bishop, 2007). This highlights the complexity of food web structure and its multiple controls on carbon export (Wassmann, 1998; Michaels and Silver, 1988).

In the present study we test the hypothesis that direct export via phytodetrital aggregates occurs during the early stage of the Kerguelen naturally iron-fertilised bloom, when zooplankton communities present in the water column are not fully developed. We further explore the relative export abilities of each carbon export mode (i.e. phytodetrital aggregates vs. fecal pellets) by looking at their variation with depth and over time and their links to spatio-temporal variations in plankton communities.

We collected sinking particles in free-drifting polyacrylamide gel and standard sediment traps. Gel traps allowed for the collection of intact natural particles as they sank in the water column (Ebersbach and Trull, 2008; Jannasch et al., 1980; McDonnell and Buesseler, 2010), and thus gave a direct "picture" of the sinking flux at the depth of trap deployment. Image analysis of particles embedded in gels provided particle statistics (e.g. number and volume fraction of each category of particle), and conversion from area to volume and from volume to carbon content, using empirical relationships, allowed for estimation of the carbon flux and the relative importance of each category of particle. In parallel, standard sediment traps serving as a reference permitted direct quantitative estimates based on bulk chemical analyses of the material collected and from ${ }^{234} \mathrm{Th}$ depletion method (Planchon et al., 2014). Then, to test our main hypothesis, the relative contribution of each category of particles was linked to the amount of carbon effectively exported in order to determine which one led the carbon export.

\section{Material and methods}

\subsection{The KEOPS2 study}

The second KErguelen Ocean and Plateau compared Study (KEOPS2) was conducted onboard the RV Marion Dufresne over and downstream of the Kerguelen Plateau, from 8 October to 30 November 2011. Sinking particle flux and composition were assessed by the use of free-drifting sediment traps deployed at six stations, inside and outside the naturally iron-fertilised area, in waters with varying biomass and surface chlorophyll $a(\mathrm{Chl} a$ ) levels (Figs. 1 and 2). For more information on the complex spatio-temporal evolution of the phytoplankton bloom over the full 2011-2012 annual cycle, we refer the reader to an animation of NASA MODIS Aqua chlorophyll images, provided as a supplementary material in Trull et al. (2014). Combination of sediment trap collection with volume-to-carbon conversion factors allowed to determine preferential modes of carbon export (Ebersbach and Trull, 2008; Ebersbach et al., 2011).

\subsection{Water column properties and biomass at each station}

In addition to trap-derived measurements, POC concentrations were estimated in the water column using a WET Labs C-Star $(6000 \mathrm{~m})$ transmissometer $(660 \mathrm{~nm}$ wavelength and $25 \mathrm{~cm}$ path length) linked to a conductivity-temperaturedepth (CTD) system (Sea-Bird SBE-911+CTD). Xmiss transmissometer data $(\%)$ were converted to POC concentrations $\left(\mu \mathrm{molL} \mathrm{L}^{-1}\right)$ following a calibration based on in situ POC measurements from Niskin bottles. A Seapoint Chelsea Aquatracka III $(6000 \mathrm{~m})$ chlorophyll fluorometer linked to the CTD was used to determine fluorescence profiles. Fluorescence was converted to chlorophyll $a$ (Chl $\left.a ; \mu \mathrm{gL}^{-1}\right)$ by comparison with total $\mathrm{Chl} a$ in situ measurements from Niskin bottles (Lasbleiz et al., 2014).

Figure 2 shows water column properties and biomass at each site. The HNLC reference station R-2 located outside the fertilised area was characterised by a relatively deep mixed layer $(96 \mathrm{~m})$, low net primary productivity (NPP) (euphotic zone $1 \%$ PAR-integrated NPP = $135 \pm 6 \mathrm{mg} \mathrm{C} \mathrm{m}^{-2} \mathrm{~d}^{-1}$; Cavagna et al., 2014), low surface chlorophyll (chlorophyll $a$ mixed layer average $=$ $0.6 \mu \mathrm{g} \mathrm{Chl} a \mathrm{~L}^{-1}$ ), and biomass (mixed-layer-integrated POC $=4.7 \mathrm{~g} \mathrm{C} \mathrm{m}^{-2}$ ). Stations E-1, E-3 and E-5 were located in an eddy-like, bathymetrically trapped recirculation feature in deep waters east of the Kerguelen Islands (stationary meander of the polar front), with a mixed layer depth varying from 33 (E-3) to $70 \mathrm{~m}(\mathrm{E}-1)$. These stations had moderate NPP $\left(523 \pm 55,686 \pm 97\right.$ and $943 \pm 113 \mathrm{mg} \mathrm{C} \mathrm{m}^{-2} \mathrm{~d}^{-1}$ respectively), Chl $a$ (0.8, 0.7 and $1.1 \mu \mathrm{g} \mathrm{Chl} a \mathrm{~L}^{-1}$ respectively), and biomass (5.3, 3 and $4.8 \mathrm{~g} \mathrm{C} \mathrm{m}^{-2}$ respectively). They were used as a time series assuming a pseudo-Lagrangian evolution (d'Ovidio et al., 2014). F-L was the only station located north of the polar front and exhibited the shallowest mixed layer $(31 \mathrm{~m})$. A3-2 was the second visit to the onplateau bloom reference station of KEOPS1 and had the deepest mixed layer (149 m). F-L and A3-2 displayed the highest NPP $\left(3.4 \pm 0.1\right.$ and $1.9 \pm 0.2 \mathrm{~g} \mathrm{Cm}^{-2} \mathrm{~d}^{-1}$ respectively), chlorophyll $a$ ( 3 and $1.8 \mu \mathrm{g} \mathrm{Chl} a \mathrm{~L}^{-1}$ respectively) and biomass $\left(6.2\right.$ and $\left.20.4 \mathrm{~g} \mathrm{Cm}^{-2}\right)$.

\subsection{Sediment trap preparation, deployments and recovery}

Two different types of trap were deployed during KEOPS2. Bulk fluxes of particulate organic carbon (POC), total particulate nitrogen (TPN), biogenic silica (BSi), particulate inorganic carbon (PIC), particulate iron (PFe; data shown in Bowie et al., 2014) and thorium $234\left({ }^{234} \mathrm{Th}\right)$ were estimated using PPS3/3 traps (Technicap, La Turbie, France). A PPS3/3 trap consists of a single cylindrical trap with an internal conical funnel at its base with a collection area of $0.125 \mathrm{~m}^{2}$ that transfers samples into a carousel of 12 cups. During KEOPS2, these traps were deployed for a maximum period 

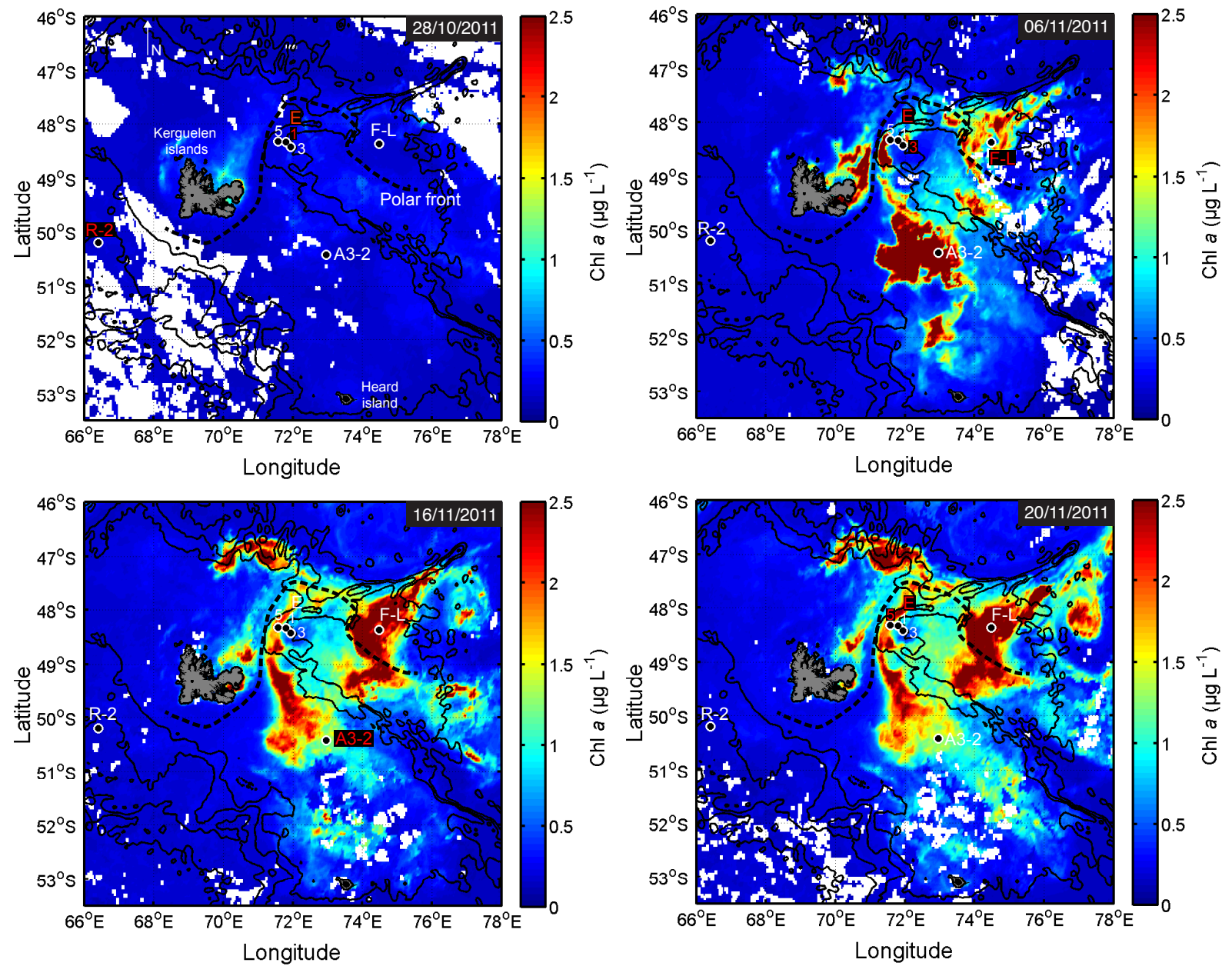

Figure 1. MODIS-Aqua satellite (CLS-CNES) images of surface chlorophyll $a$ concentration (Chl $a$ ) at different bloom stages from 28 October to 20 November 2011. Images show free-drifting sediment trap deployment locations in contrasting biomass levels. On each map, red labels represent the station(s) sampled at the date of the map \pm 3 days.

of 6 days. Cups were filled with brine with a salinity of $\sim$ $52 \mathrm{psu}$, made by freezing filtered $(0.2 \mu \mathrm{m}$ pore size $)$ surface seawater. Some cups were also amended with mercuric chloride $\left(1 \mathrm{gL}^{-1}\right)$ as a biocide (as detailed in Table 4). No poison was added to the cups used for trace metal studies (Bowie et al., 2014).

To examine sinking flux characteristics (particle type, number and size), intact particles were also collected in cylindrical polyacrylamide gel-filled sediment traps with a collection area of $0.011 \mathrm{~m}^{2}$. These deployments lasted less than 2 days so as not to overload the gels (Table 1). Polyacrylamide gels were prepared following the method developed by Lundsgaard (1995), modified as described in Ebersbach and Trull (2008).

Due to different required deployment durations (shorter for gel traps to avoid overloading; see above), each category of trap was deployed on separate arrays, except at A32 (combined deployment, Table 1). All separated deployments of gel and PPS3/3 traps overlapped in time and lo- cation (except at station E-3, where they were successive), to optimise the collection of similar particle fields. The arrays had broadly the same design consisting of a surface float sustaining a mooring line where the traps were fixed at different depths. PPS $3 / 3$ traps were fixed at $210 \mathrm{~m}$, and one to four gel traps, depending on the station, were fixed at $110,210,330$ and $430 \mathrm{~m}$. Wave-induced motions were dampened by an elastic link to keep the traps at a constant depth (Trull et al., 2008). Pressure sensors mounted on the deepest gel trap and PPS3/3 trap on most of the arrays confirmed very small vertical motions during the deployments, with depth standard deviations ranging from $0.6 \mathrm{~m}$ at E-1 to $2.4 \mathrm{~m}$ at E-5 (Table 1). The average trap drift speed of $8.5 \pm 5 \mathrm{~cm} \mathrm{~s}^{-1}$ was in the range of horizontal velocities determined by drogued drifter trajectories (Zhou et al., 2014). Inclinometers recorded small tilts of the mooring lines (from $0.3 \pm 1^{\circ}$ at $\mathrm{E}-3$ to a maximum of $4 \pm 1.7^{\circ}$ at E-5), guaranteeing minimum perturbation of particle collection due to hydrodynamic conditions. No particular difficulties were encountered 


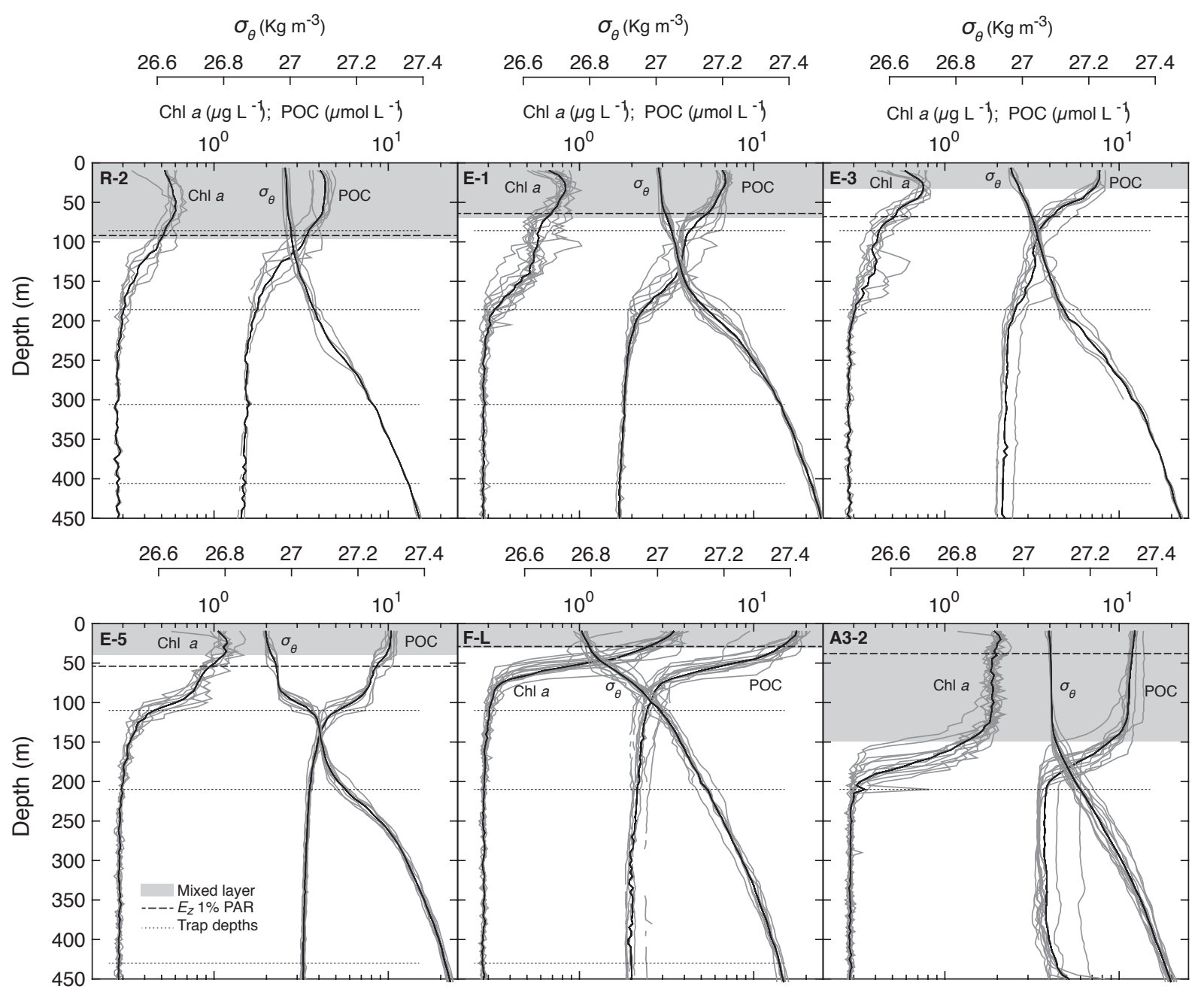

Figure 2. Water column properties and biomass at each site. Chl $a$ : chlorophyll $a\left(\mu \mathrm{L} \mathrm{L}^{-1}\right) ; \sigma_{\theta}$ : potential density anomaly (kg m $\left.{ }^{-3}\right)$; POC: particulate organic carbon $\left(\mu \mathrm{molL} \mathrm{L}^{-1}\right)$. Grey lines indicate CTD profiles and black lines represent their average values. $E_{Z} 1 \%$ PAR: base of the euphotic zone assumed at $1 \%$ of the photosynthetic available radiation (PAR).

during trap recoveries, ensuring unperturbed gel structure. The seawater overlying the gels was removed directly after recovery to prevent particles collected in the trap cylinder during the recovery from entering the gels. Unfortunately, the PPS3/3 trap array deployed at R-2 was lost.

\subsection{Chemical analysis}

Protocols used for particulate organic carbon (POC), total particulate nitrogen (TPN), particulate inorganic carbon (PIC) and biogenic silica (BSi) analyses are described in Trull et al. (2008). ${ }^{234} \mathrm{Th}$ flux analysis is detailed in Planchon et al. (2014).

\subsection{Image analysis}

Within a few hours after recovery, each gel was photographed onboard against a laser-etched glass grid of 36 cells (each
$14 \mathrm{~mm} \times 12.5 \mathrm{~mm}$ ) at a magnification of $\times 6.5$ using a light field transmitted illumination and a Zeiss Stemi 2000-CS stereomicroscope coupled to a Leica DFC-280 1.5 MP digital camera and Leica Firecam software on an Apple iMac G4 computer. Observations at higher magnification (from $\times 10$ to $\times 50$ ) confirmed particle identifications when needed.

Pictures of incomplete grid cells, with inequally distributed particles or large zooplankton, were removed from the analysis to avoid bias. Ten grid cells per gel (total of 180 pictures) were selected randomly. The average sum of the surface analysed per gel was $15.7 \pm 0.7 \mathrm{~cm}^{2}$, corresponding to $14.3 \pm 0.7 \%$ of the trap collection area.

Particles collected in gels (Fig. 3) were phytodetrital aggregates (PA), cylindrical fecal pellets (CFP), oval fecal pellets, fecal aggregates (FA) and diatoms in the form of chains (e.g. the pennate Fragilariopsis spp.) or single cells (e.g. the centric Thalassiosira spp.). A few mesozooplankton specimens were collected (less than 10 per gel), and were mostly 
Table 1. Deployment schedules for free-drifting sediment trap arrays.

\begin{tabular}{|c|c|c|c|c|c|c|c|c|c|c|c|}
\hline Area & Site ID & Array & $\begin{array}{l}\text { Trap depths } \\
\text { (m) }\end{array}$ & $\begin{array}{c} \pm \mathrm{SD} \\
(\mathrm{m})\end{array}$ & Event & $\begin{array}{l}\text { Time } \\
\text { (UTC)* }^{*}\end{array}$ & Latitude & Longitude & $\begin{array}{l}\text { Duration } \\
\text { (days) }\end{array}$ & $\begin{array}{l}\text { Drift } \\
(\mathrm{km})\end{array}$ & $\begin{array}{l}\text { Tilt } \pm \text { SD } \\
\quad\left({ }^{\circ}\right)\end{array}$ \\
\hline \multirow{4}{*}{$\begin{array}{l}\text { HNLC } \\
\text { reference }\end{array}$} & \multirow[t]{4}{*}{$\mathrm{R}-2$} & \multirow[t]{2}{*}{ Gel traps } & \multirow[t]{2}{*}{$110,210,330,430$} & \multirow[t]{2}{*}{0.8} & Deploy & 26 Oct $2011,15: 33$ & $50^{\circ} 21.58^{\prime} \mathrm{S}$ & $66^{\circ} 42.93^{\prime} \mathrm{E}$ & \multirow[t]{2}{*}{0.92} & \multirow[t]{2}{*}{3.8} & \multirow[t]{2}{*}{-} \\
\hline & & & & & Recover & 27 Oct $2011,13: 33$ & $50^{\circ} 20.10^{\prime} \mathrm{S}$ & $66^{\circ} 40.69^{\prime} \mathrm{E}$ & & & \\
\hline & & \multirow[t]{2}{*}{$P$ trap } & \multirow[t]{2}{*}{210} & \multirow[t]{2}{*}{-} & Deploy & 18 Oct $2011,00: 56$ & $50^{\circ} 42.57^{\prime} \mathrm{S}$ & $66^{\circ} 41.47^{\prime} \mathrm{E}$ & \multirow[t]{2}{*}{-} & \multirow[t]{2}{*}{-} & \multirow[t]{2}{*}{-} \\
\hline & & & & & Lost & - & - & - & & & \\
\hline \multirow{12}{*}{$\begin{array}{l}\text { Off-plateau } \\
\text { meander } \\
\text { (time series) }\end{array}$} & \multirow[t]{4}{*}{ E-1 } & \multirow[t]{2}{*}{ Gel traps } & \multirow[t]{2}{*}{$110,210,330,430$} & \multirow[t]{2}{*}{1} & Deploy & 28 Oct $2011,23: 00$ & $48^{\circ} 28.72^{\prime} \mathrm{S}$ & $72^{\circ} 12.68^{\prime} \mathrm{E}$ & \multirow[t]{2}{*}{1.25} & \multirow[t]{2}{*}{2.9} & \multirow[t]{2}{*}{-} \\
\hline & & & & & Recover & 30 Oct $2011,05: 00$ & $48^{\circ} 27.48^{\prime} \mathrm{S}$ & $72^{\circ} 11.27^{\prime} \mathrm{E}$ & & & \\
\hline & & \multirow[t]{2}{*}{$P$ trap } & \multirow[t]{2}{*}{210} & \multirow[t]{2}{*}{0.6} & Deploy & 29 Oct $2011,10: 35$ & $48^{\circ} 29.66^{\prime} \mathrm{S}$ & $72^{\circ} 14.28^{\prime} \mathrm{E}$ & \multirow[t]{2}{*}{5.32} & \multirow[t]{2}{*}{35} & \multirow[t]{2}{*}{$2.5 \pm 0.7$} \\
\hline & & & & & Recover & 3 Nov $2011,18: 14$ & $48^{\circ} 38.44^{\prime} \mathrm{S}$ & $71^{\circ} 48.99^{\prime} \mathrm{E}$ & & & \\
\hline & \multirow[t]{4}{*}{ E-3 } & \multirow[t]{2}{*}{ Gel traps } & \multirow[t]{2}{*}{$110,210,430$} & \multirow[t]{2}{*}{0.9} & Deploy & 3 Nov $2011,14: 30$ & $48^{\circ} 41.92^{\prime} \mathrm{S}$ & $71^{\circ} 57.89^{\prime} \mathrm{E}$ & \multirow[t]{2}{*}{1.02} & 4 & - \\
\hline & & & & & Recover & 4 Nov $2011,15: 00$ & $48^{\circ} 43.90^{\prime} \mathrm{S}$ & $71^{\circ} 56.66^{\prime} \mathrm{E}$ & & & \\
\hline & & $\mathrm{P}$ trap & 210 & 0.7 & Deploy & 5 Nov $2011,07: 52$ & $48^{\circ} 42.06^{\prime} \mathrm{S}$ & $71^{\circ} 56.96^{\prime} \mathrm{E}$ & 5.11 & 43 & $0.3 \pm 1$ \\
\hline & & & & & Recover & 10 Nov $2011,10: 37$ & $48^{\circ} 40.77^{\prime} \mathrm{S}$ & $72^{\circ} 32.08^{\prime} \mathrm{E}$ & & & \\
\hline & E-5 & Gel traps & $110,210,430$ & 0.9 & Deploy & 18 Nov $2011,13: 50$ & $48^{\circ} 25.07^{\prime} \mathrm{S}$ & $71^{\circ} 59.84^{\prime} \mathrm{E}$ & 1.06 & 10.1 & - \\
\hline & & & & & Recover & 19 Nov $2011,15: 17$ & $48^{\circ} 30.25^{\prime} \mathrm{S}$ & $71^{\circ} 57.42^{\prime} \mathrm{E}$ & & & \\
\hline & & $\mathrm{P}$ trap & 210 & 2.4 & Deploy & 18 Nov $2011,14: 42$ & $48^{\circ} 25.03^{\prime} \mathrm{S}$ & $71^{\circ} 58.11^{\prime} \mathrm{E}$ & 1.55 & 15.1 & $4 \pm 1.7$ \\
\hline & & & & & Recover & 20 Nov $2011,03: 54$ & $48^{\circ} 33.16^{\prime} \mathrm{S}$ & $71^{\circ} 56.86^{\prime} \mathrm{E}$ & & & \\
\hline North polar & F-L & Gel traps & $110,210,430$ & 0.9 & Deploy & 6 Nov $2011,14: 30$ & $48^{\circ} 31.64^{\prime} \mathrm{S}$ & $74^{\circ} 39.53^{\prime} \mathrm{E}$ & 0.92 & 14.2 & - \\
\hline front & & & & & Recover & 7 Nov $2011,12: 37$ & $48^{\circ} 36.60^{\prime} \mathrm{S}$ & $74^{\circ} 48.40^{\prime} \mathrm{E}$ & & & \\
\hline On-plateau & A3-2 & P trap $(+$ gel $)$ & $210(210)$ & 1 & Deploy & 15 Nov $2011,21: 28$ & $50^{\circ} 37.80^{\prime} \mathrm{S}$ & $72^{\circ} 4.81^{\prime} \mathrm{E}$ & 1.85 & 10.4 & $1 \pm 0.9$ \\
\hline reference & & & & & Recover & 17 Nov $2011,17: 46$ & $50^{\circ} 42.52^{\prime} \mathrm{S}$ & $72^{\circ} 9.67^{\prime} \mathrm{E}$ & & & \\
\hline
\end{tabular}

* Times and locations are at the start of the deck operation.

represented by copepods (adult and copepodite stages) and appendicularians. Foraminifera and radiolarians were also occasionally observed. Phytodetrital aggregates were loose and green, while fecal aggregates contained dense, brown material. Most cylindrical fecal pellets had sharp edges and relatively constant diameters, but some were tapered along their length and had blurred edges composed of unpacked fecal material or attached phytodetritus (Fig. 3, panel b).

A preliminary image analysis was conducted to select the best analysis method in terms of particle identification. Particles were classified into three main categories based on their significant contribution to the flux: phytodetrital aggregates, cylindrical fecal pellets and fecal aggregates. A fourth category, oval fecal pellets, was rare (less than one pellet per image in total), and its contribution to the flux was assumed negligible. Pictures were converted to binary images, with threshold levels adjusted manually on each picture to ensure a minimum alteration of particle areas. The average alteration of particle area estimated on a subsample was an increase of $21.6 \pm 7 \%(n=169)$ for particles with irregular shapes (e.g. aggregates sensu lato including phytodetrital and fecal aggregates), and an increase of $11.6 \pm 7 \%(n=44)$ for cylindrical fecal pellets. Cylindrical fecal pellet and aggregate areas were systematically corrected for this overestimation.

Pictures were analysed with the US National Institutes of Health's free software ImageJ. Typical shapes of each category of particle were determined manually on a subsample of particles. MATLAB routines using specific sets of shape descriptors were then applied to all images to identify and separate each category of particle. Because fecal and phytodetrital aggregates had similar complex shapes, automated

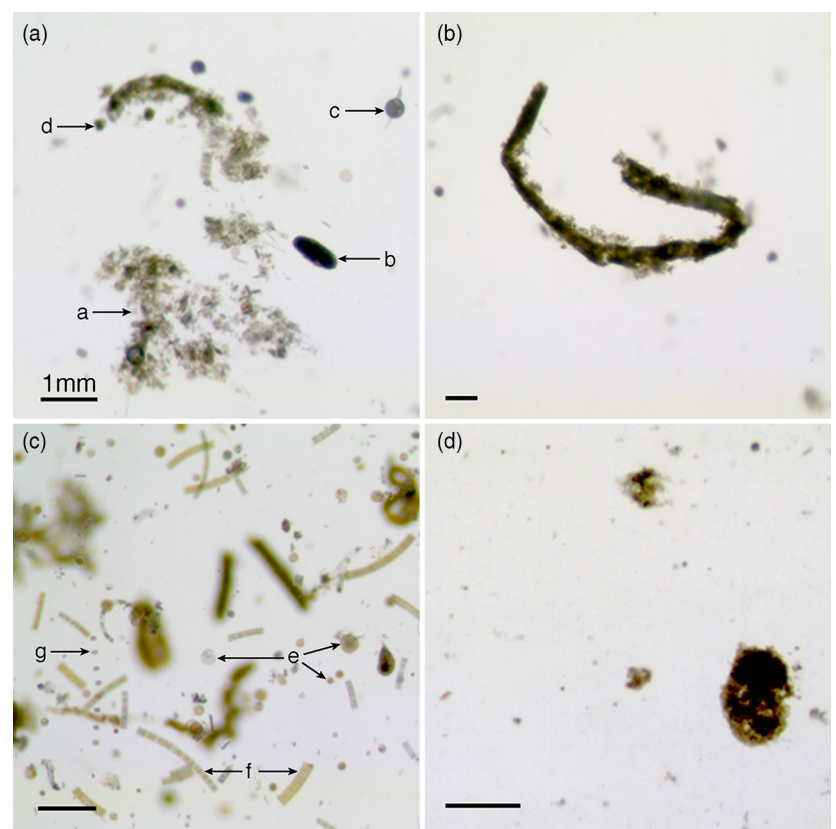

Figure 3. High-resolution pictures of particles embedded in polyacrylamide gels showing the main categories of particles collected. Panel (a) - a: Phytodetrital aggregate; b: oval fecal pellet; $b$ : radiolarian, d: foraminifera; panel (b) large cylindrical fecal pellet; panel (c) - e: small and large centric diatom single cells; f: chains of pennate diatoms of the genera Fragilariopsis spp., g: chain of small centric diatom cells; panel (d) fecal aggregate. Note the difference in compactness and optical density between phytodetrital and fecal aggregates. 
routines could not separate these particles efficiently. All fecal material was thus isolated manually from all other particles based on the assumption that fecal matter is brown and denser than biologically unprocessed phytoplankton (Ebersbach et al., 2011). From the resulting set of pictures, fecal aggregates were easily separated from cylindrical fecal pellets due to their very contrasted shapes. Tests on the efficiency of our automated selection, conducted on a large sample, showed that $93.4 \%(n=397)$ of cylindrical fecal pellets and $67.2 \%(n=171)$ of fecal aggregates were correctly identified by the set of shape descriptors chosen.

All particle characteristics investigated in this study and their units are reported in Table 2. An area cut-off applied at $0.004 \mathrm{~mm}^{2}(0.07 \mathrm{~mm}$ equivalent spherical diameter) removed all "fake particles" deriving from small gel imperfections and glass grid or microscope lens cleanliness. This cutoff removed $38 \%$ of the total number of particles (mostly spurious particles and small single cells) but represented a loss of only $5.2 \%$ of the total area of particles in the images, introducing a negligible bias.

Aggregate area was converted to equivalent spherical diameter (ESD) assuming spherical shape, and the volume was calculated from the ESD. Because cylindrical fecal pellets were not always straight, their volume could not be accurately measured directly from their length and was calculated from their perimeter and area (independent of pellet curvature), assuming a cylinder. The radius $r$ of the cylinder section was determined by finding the minimum root of the polynomial

$4 r^{2}-P r+A=0$,

where $P$ is the perimeter and $A$ is the projected area of the aggregate. The length $L$ was calculated from the projected area and radius using the formula

$L=A / 2 r$.

The volume was then calculated from the radius and length.

The conversion from volume to carbon content was done by using different ratios and relationships depending on the particle considered. Figure 4 shows the relationship between carbon content and particle volume for different algorithms from the literature and those selected in this study. Based on values published by González and Smetacek (1994), the volume of cylindrical fecal pellets was converted to their organic carbon content using a ratio of $0.036 \mathrm{mg} \mathrm{mm}^{-3}$ (Fig. 4, line 2), as an average value for copepod (Fig. 4, line 1), and euphausiid fecal pellets (Fig. 4, line 3). For fecal aggregates, we used the power relationship between POC content and aggregate volume $V, \operatorname{POC}(\mu \mathrm{g})=1.05 V\left(\mathrm{~mm}^{3}\right)^{0.51}$, based on the fractal decrease in carbon content with size and determined empirically by Alldredge (1998) for fecal marine snow (Fig. 4, line 4). The volume of phytodetrital aggregates was converted to carbon content using also a power relationship determined by Alldredge (1998) for diatom marine

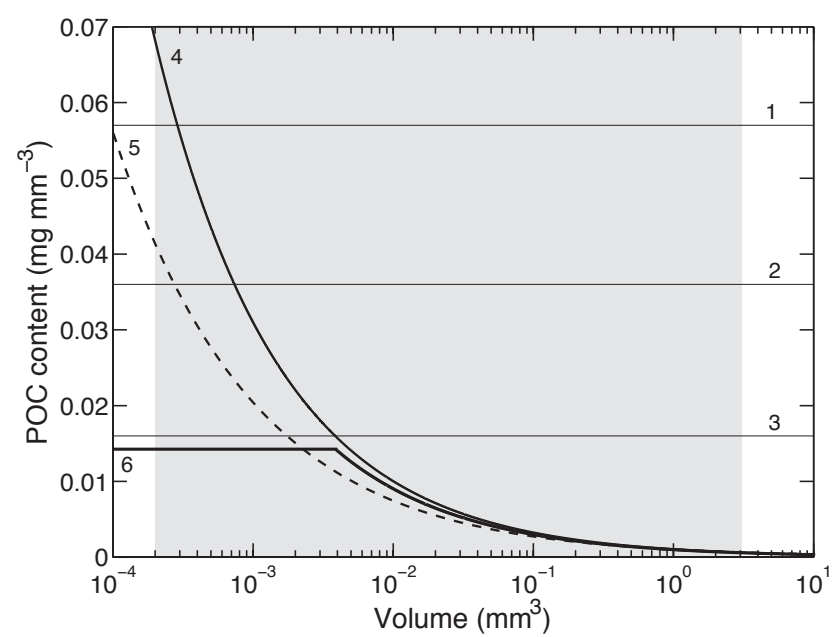

Figure 4. Empirical relationships of particulate organic carbon (POC) content as a function of volume for different categories of sinking particles. 1, 2 and 3: copepod fecal pellets, average of euphausiids and copepod fecal pellets and euphausiids fecal pellets respectively (González and Smetacek, 1994); 4: fecal marine snow (Alldredge, 1998); 5: diatom marine snow (Alldredge, 1998); 6: small and large aggregates (sensu lato) respectively (Ebersbach and Trull, 2008). The grey area represents the size range of particles processed in this study. Note the constant carbon mass per unit volume in fecal pellets based on solid geometry (linear relationship) and its decrease with increasing volume scaled on fractal geometry (power relationship) in the case of aggregates.

snow, POC $(\mu \mathrm{g})=0.97 V\left(\mathrm{~mm}^{3}\right)^{0.56}$ (Fig. 4, line 5), assuming aggregates composed of phytoplankton not biologically processed. In contrast to Ebersbach and Trull (2008; Fig. 4, line 6), very small particles (large single cells and aggregates composed of few cells) were included in the category of phytodetrital aggregates and their volume-to-carbon conversion was done using the same relationship (Fig. 4, line 5).

Particle number and volume fluxes are presented in Sect. 3 as a function of size spectra. All particles were binned in 10 size classes spaced logarithmically to give the best representation of the whole size range (Jackson et al., 1997, 2005). To avoid bias, bins containing five or fewer particles were not included in the flux spectrum analyses, as recommended by Jackson et al. (2005).

\section{Results}

\subsection{Particles collected in polyacrylamide gel-filled sediment traps}

\subsubsection{Particle number, projected area and volume fluxes}

Despite variations in deployment duration among sites exceeding $80 \%$ (between 0.9 and 5.3 days, Table 1), an observation of raw images (Fig. 5) gives a broad preliminary 
Table 2. Particle characteristics and bins for phytodetrital aggregates, cylindrical fecal pellets and fecal aggregates.

\begin{tabular}{|c|c|c|c|c|c|c|c|c|c|c|}
\hline \multicolumn{5}{|l|}{ Characteristics name } & \multicolumn{3}{|l|}{ Unit } & \multicolumn{3}{|c|}{ Definition } \\
\hline \multicolumn{5}{|l|}{ Projected area } & \multicolumn{3}{|l|}{$\mathrm{cm}^{2}$} & \multicolumn{3}{|c|}{ Pixel area of the particle image } \\
\hline \multicolumn{5}{|l|}{ Volume } & \multicolumn{3}{|l|}{$\mathrm{cm}^{3}$} & \multicolumn{3}{|c|}{ Volume calculated from area } \\
\hline \multicolumn{5}{|c|}{ Equivalent spherical diameter (ESD) } & \multicolumn{3}{|l|}{$\mathrm{cm}$} & \multicolumn{3}{|c|}{ Diameter of a sphere with the same image area } \\
\hline \multicolumn{5}{|c|}{ Perimeter } & \multicolumn{3}{|l|}{$\mathrm{cm}$} & \multicolumn{3}{|c|}{ Sum of pixel lengths at particle edge } \\
\hline \multicolumn{5}{|l|}{ Length } & \multicolumn{3}{|c|}{$\mathrm{cm}$} & \multicolumn{3}{|c|}{ Major axis of ellipse fit to particle } \\
\hline \multicolumn{5}{|l|}{ Numerical flux } & \multicolumn{3}{|c|}{$\mathrm{m}^{-2} \mathrm{~d}^{-1}$} & \multicolumn{3}{|c|}{ Number flux of sinking particles } \\
\hline \multicolumn{5}{|l|}{ Volume flux } & \multicolumn{3}{|c|}{$\mathrm{cm}^{3} \mathrm{~m}^{-2} \mathrm{~d}^{-1}$} & \multicolumn{3}{|c|}{ Volume flux of sinking particles } \\
\hline \multicolumn{5}{|l|}{ Carbon flux } & \multicolumn{3}{|c|}{$\operatorname{mgCm} \mathrm{m}^{-2} \mathrm{~d}^{-1}$} & \multicolumn{3}{|c|}{ Organic carbon flux in sinking particles } \\
\hline \multicolumn{5}{|l|}{ Number flux spectrum } & \multicolumn{3}{|c|}{$\mathrm{cm}^{-1} \mathrm{~m}^{-2} \mathrm{~d}^{-1}$} & \multicolumn{3}{|c|}{ Number flux per unit ESD size interval } \\
\hline \multicolumn{5}{|l|}{ Volume flux spectrum } & \multicolumn{3}{|c|}{$\mathrm{cm}^{3} \mathrm{~m}^{-2} \mathrm{~d}^{-1} \mathrm{~cm}^{-1}$} & \multicolumn{3}{|c|}{ Volume flux per unit ESD size interval } \\
\hline \multicolumn{5}{|c|}{ Number, volume and carbon flux fractional contributions } & \multicolumn{3}{|l|}{ none } & \multicolumn{3}{|c|}{ Number, volume and carbon flux of particle types as a fraction of total } \\
\hline Bins $(\mathrm{cm})$ & 1 & 2 & 3 & 4 & 5 & 6 & 7 & 8 & 9 & 10 \\
\hline Lower limits (ESD) & 0.0071 & 0.0102 & 0.0145 & 0.0207 & 0.0296 & 0.0422 & 0.0603 & 0.0860 & 0.1228 & 0.1752 \\
\hline Upper limits (ESD) & 0.0102 & 0.0145 & 0.0207 & 0.0296 & 0.0422 & 0.0603 & 0.0860 & 0.1228 & 0.1752 & - \\
\hline Centre (ESD) & 0.0087 & 0.0124 & 0.0176 & 0.0252 & 0.0359 & 0.0513 & 0.0732 & 0.1044 & 0.1490 & - \\
\hline
\end{tabular}

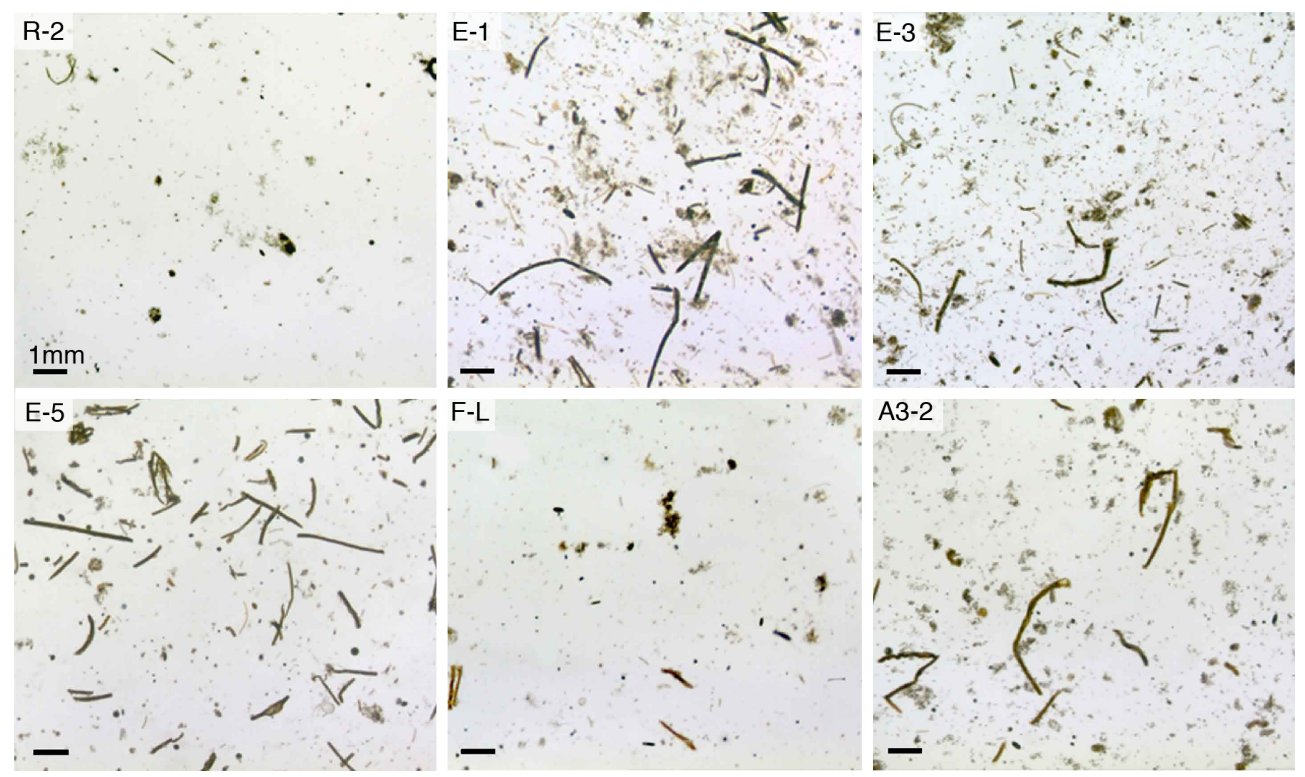

Figure 5. Images of sinking particles embedded in polyacrylamide gels, collected at each site at $210 \mathrm{~m}$. Comparison of images suggests differences in terms of particles abundance and nature at each site.

indication on flux differences in terms of particle abundance (e.g. low fluxes at R-2 and F-L, and higher at E stations and A3-2). The lowest particle numbers, projected particle area and volume fluxes were collected at R-2 and F-L (Table 3 and Fig. 6), with particle volume fluxes of $2.5 \pm 1$ and $3 \pm 0.7 \mathrm{~cm}^{3} \mathrm{~m}^{-2} \mathrm{~d}^{-1}$ respectively (all depths averaged). In contrast, high fluxes were collected at $\mathrm{E}$ stations with an average volume flux of $7.5 \pm 3 \mathrm{~cm}^{3} \mathrm{~m}^{-2} \mathrm{~d}^{-1}$ (all E stations and depths averaged). Station A3-2 also presented a relatively high flux of $6.1 \mathrm{~cm}^{3} \mathrm{~m}^{-2} \mathrm{~d}^{-1}$.

Phytodetrital aggregates dominated in number at most stations and depths $(49 \pm 10 \%$ of the total number of particles for all stations and depths averaged). Particles not selected automatically as phytodetrital aggregates, cylindrical fecal pellets or fecal aggregates ("others" in Table 3) repre- sented the second-largest numerical fraction $(38 \pm 8 \%)$ but less than $9 \%$ of the total projected particle area, and thus were assumed negligible in volume fluxes. Phytodetrital aggregates also dominated the volume fluxes $(45.3 \pm 22 \%$, all stations and depths averaged), with a maximum of $70 \%$ at A3-2. However, volumes of cylindrical fecal pellets collected at E-5 (44 $\pm 33 \%$, all depths averaged) and volumes of fecal aggregates collected at F-L ( $57 \pm 18 \%$, all depths averaged) represented the highest fractions at these stations.

Projected area fluxes at all stations and depths (Fig. 6) showed a clear attenuation of the total flux between 210 and $430 \mathrm{~m}$ (loss of $38 \pm 21 \%$ on average), with a maximum attenuation of $74 \%$ at E-5 (Fig. 6a). A decrease in the flux of cylindrical fecal pellets with depth was combined with an increase in the flux of aggregates (mainly phytodetrital), except 
Table 3. Total numerical, volume and particulate organic carbon (POC) fluxes and fractional contributions of each category of particle. Maximum and minimum fluxes are indicated in bold. PA: phytodetrital aggregates; CFP: cylindrical fecal pellets; FA: fecal aggregates; O: others.

\begin{tabular}{|c|c|c|c|c|c|c|c|c|c|c|c|c|c|c|}
\hline \multirow[t]{2}{*}{$\begin{array}{l}\text { Site } \\
\text { ID }\end{array}$} & \multirow[t]{2}{*}{$\begin{array}{l}\text { Depth } \\
\text { (m) }\end{array}$} & \multirow[t]{2}{*}{$\begin{array}{l}\text { Numerical flux } \\
\left(\# 10^{4} \mathrm{~m}^{-2} \mathrm{~d}^{-1}\right)\end{array}$} & \multicolumn{4}{|c|}{$\begin{array}{l}\text { Fractional } \\
\text { contributions }\end{array}$} & \multirow[t]{2}{*}{$\begin{array}{l}\text { Volume flux } \\
\left(\mathrm{cm}^{3} \mathrm{~m}^{-2} \mathrm{~d}^{-1}\right)\end{array}$} & \multicolumn{3}{|c|}{$\begin{array}{c}\text { Fractional } \\
\text { contributions }\end{array}$} & \multirow[t]{2}{*}{$\begin{array}{c}\text { POC flux } \\
\left(\mathrm{mgCm}^{-2} \mathrm{~d}^{-1}\right)\end{array}$} & \multicolumn{3}{|c|}{$\begin{array}{c}\text { Fractional } \\
\text { contributions }\end{array}$} \\
\hline & & & PA & CFP & FA & $\mathrm{O}$ & & PA & CFP & FA & & $\mathrm{PA}$ & CFP & FA \\
\hline \multirow[t]{4}{*}{ R-2 } & 110 & 97 & 0.45 & 0.04 & 0.07 & 0.44 & 4 & 0.43 & 0.14 & 0.43 & 43 & 0.3 & 0.48 & 0.22 \\
\hline & 210 & 84 & 0.46 & 0.03 & 0.05 & 0.46 & 2.8 & 0.39 & 0.14 & 0.47 & 30 & 0.34 & 0.46 & 0.2 \\
\hline & 330 & 72 & 0.49 & 0.02 & 0.04 & 0.45 & 1.7 & 0.52 & 0.15 & 0.33 & 20 & 0.39 & 0.43 & 0.18 \\
\hline & 430 & 91 & 0.49 & 0.01 & 0.04 & 0.46 & 1.6 & 0.61 & 0.04 & 0.35 & 16 & 0.63 & 0.13 & 0.24 \\
\hline \multirow[t]{4}{*}{ E-1 } & 110 & 178 & 0.52 & 0.16 & 0.04 & 0.28 & 5.2 & 0.34 & 0.45 & 0.21 & 112 & 0.18 & 0.76 & 0.06 \\
\hline & 210 & 208 & 0.6 & 0.07 & 0.03 & 0.3 & 13 & 0.56 & 0.27 & 0.17 & 176 & 0.24 & 0.71 & 0.05 \\
\hline & 330 & 142 & 0.51 & 0.07 & 0.06 & 0.36 & 8 & 0.3 & 0.25 & 0.45 & 108 & 0.19 & 0.67 & 0.14 \\
\hline & 430 & 184 & 0.65 & 0.02 & 0.02 & 0.31 & 12.3 & 0.78 & 0.1 & 0.12 & 96 & 0.47 & 0.46 & 0.07 \\
\hline \multirow[t]{3}{*}{ E-3 } & 110 & 131 & 0.47 & 0.12 & 0.05 & 0.36 & 4.8 & 0.4 & 0.24 & 0.36 & 67 & 0.25 & 0.63 & 0.12 \\
\hline & 210 & 216 & 0.58 & 0.05 & 0.03 & 0.34 & 6.6 & 0.61 & 0.19 & 0.2 & 85 & 0.4 & 0.52 & 0.08 \\
\hline & 430 & 92 & 0.61 & 0.02 & 0.04 & 0.33 & 7.6 & 0.73 & 0.1 & 0.17 & 56 & 0.43 & 0.47 & 0.1 \\
\hline \multirow[t]{3}{*}{ E-5 } & 110 & 225 & 0.34 & 0.33 & 0.04 & 0.29 & 6.1 & 0.15 & 0.72 & 0.13 & 180 & 0.08 & 0.88 & 0.04 \\
\hline & 210 & 194 & 0.4 & 0.19 & 0.06 & 0.35 & 7.9 & 0.28 & 0.51 & 0.21 & 177 & 0.11 & 0.82 & 0.07 \\
\hline & 430 & 93 & 0.49 & 0.02 & 0.04 & 0.45 & 3.5 & 0.8 & 0.08 & 0.12 & 30 & 0.55 & 0.34 & 0.11 \\
\hline \multirow[t]{3}{*}{ F-L } & 110 & 85 & 0.31 & 0.12 & 0.05 & 0.52 & 2.1 & 0.16 & 0.48 & 0.36 & 45 & 0.11 & 0.8 & 0.09 \\
\hline & 210 & 87 & 0.32 & 0.07 & 0.07 & 0.54 & 3.5 & 0.15 & 0.19 & 0.66 & 38 & 0.16 & 0.64 & 0.2 \\
\hline & 430 & 56 & 0.46 & 0.04 & 0.09 & 0.41 & 3.3 & 0.23 & 0.09 & 0.68 & 26 & 0.26 & 0.41 & 0.33 \\
\hline A3-2 & 210 & 123 & 0.65 & 0.04 & 0.03 & 0.28 & 6.1 & 0.7 & 0.16 & 0.14 & 66 & 0.41 & 0.52 & 0.07 \\
\hline
\end{tabular}

at R-2, where a general flux attenuation was observed (all particle categories), and only a small increase in phytodetrital aggregates at $430 \mathrm{~m}$.

Fluxes at $\mathrm{E}$ stations at 110 and $210 \mathrm{~m}$ decreased with time between E-1 and E-3, followed by a strong increase in cylindrical fecal pellet flux at E-5 (Fig. 6c).

\subsubsection{Number and volume flux spectra}

Smallest particles were the most numerous at every site and depth (Fig. 7). Particle numbers decreased by more than 3 orders of magnitude for a 1 order of magnitude increase in size $(0.008-0.07 \mathrm{~cm})$, leading to slopes values around -3 , and therefore in the range expected for particle size distribution (PSD) in natural waters ( -2 to -5 ; Buonassissi and Dierssen, 2010; Guidi et al., 2009). Phytodetrital aggregates, representing the largest fraction of total particles, broadly followed the same spectra. Most cylindrical fecal pellets and fecal aggregates were middle-sized (ESD of $0.015-0.1 \mathrm{~cm}$ ) with maximum abundances in the range $0.015-0.03 \mathrm{~cm}$. E5 presented the highest abundance of large fecal pellets $(0.025$ to $0.035 \mathrm{~cm})$, with values exceeding $2 \times 10^{7}$ and $7 \times$

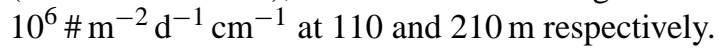

At all sites, most of the volume flux of phytodetrital aggregates was carried by middle-sized particles (ESD of 0.01$0.03 \mathrm{~cm}$ ), due to the small contribution of large aggregates to the total number. Middle-sized and large cylindrical fecal pellets and fecal aggregates (ESD of $0.03-0.07 \mathrm{~cm}$ ) carried most of the volume flux, but again the largest particles did not bring the highest contribution due to their rarity relative to smaller particles (except at R-2, where the largest cylindrical fecal pellets and fecal aggregates contributed significantly to the volume flux).

The most notable change in the number flux spectra with depth was observed for middle-sized cylindrical fecal pellets at $E$ stations, for which a decrease in number was generally combined with an increase in size. E-1 presents the best illustration, with most of the cylindrical fecal pellets with a size around $0.01 \mathrm{~cm}$ at $110 \mathrm{~m}$ increasing to $0.06 \mathrm{~cm}$ at $210 \mathrm{~m}$.

\subsubsection{POC flux from image analysis}

The lowest carbon fluxes were estimated at R-2 and F-L (Table 3), with values of $27 \pm 12$ and $36 \pm 10 \mathrm{mg} \mathrm{Cm}^{-2} \mathrm{~d}^{-1}$ respectively (all depths averaged). The highest carbon fluxes were observed at $\mathrm{E}$ stations $\left(107 \pm 33 \mathrm{mg} \mathrm{C} \mathrm{m}^{-2} \mathrm{~d}^{-1}\right.$, all $\mathrm{E}$ stations and depths averaged), with a maximum value of $180 \mathrm{mg} \mathrm{Cm}^{-2} \mathrm{~d}^{-1}$ at E-5, $110 \mathrm{~m}$. A3-2 presented a moderate carbon flux of $66 \mathrm{mg} \mathrm{Cm}^{-2} \mathrm{~d}^{-1}$ at $210 \mathrm{~m}$.

Cylindrical fecal pellets carried most of the carbon flux at all stations and depths, with an average fractional contribution of $56 \pm 19 \%$ (Table 3). This was particularly true at E stations, where fecal pellets drove on average $63 \pm 17 \%$ of the carbon flux (maximum of $88 \%$ at E-5, $110 \mathrm{~m}$ ), and at F-L (62 $\pm 20 \%$, all depths averaged). However, at several stations, a transition was observed at $430 \mathrm{~m}$, where phytodetrital ag- 


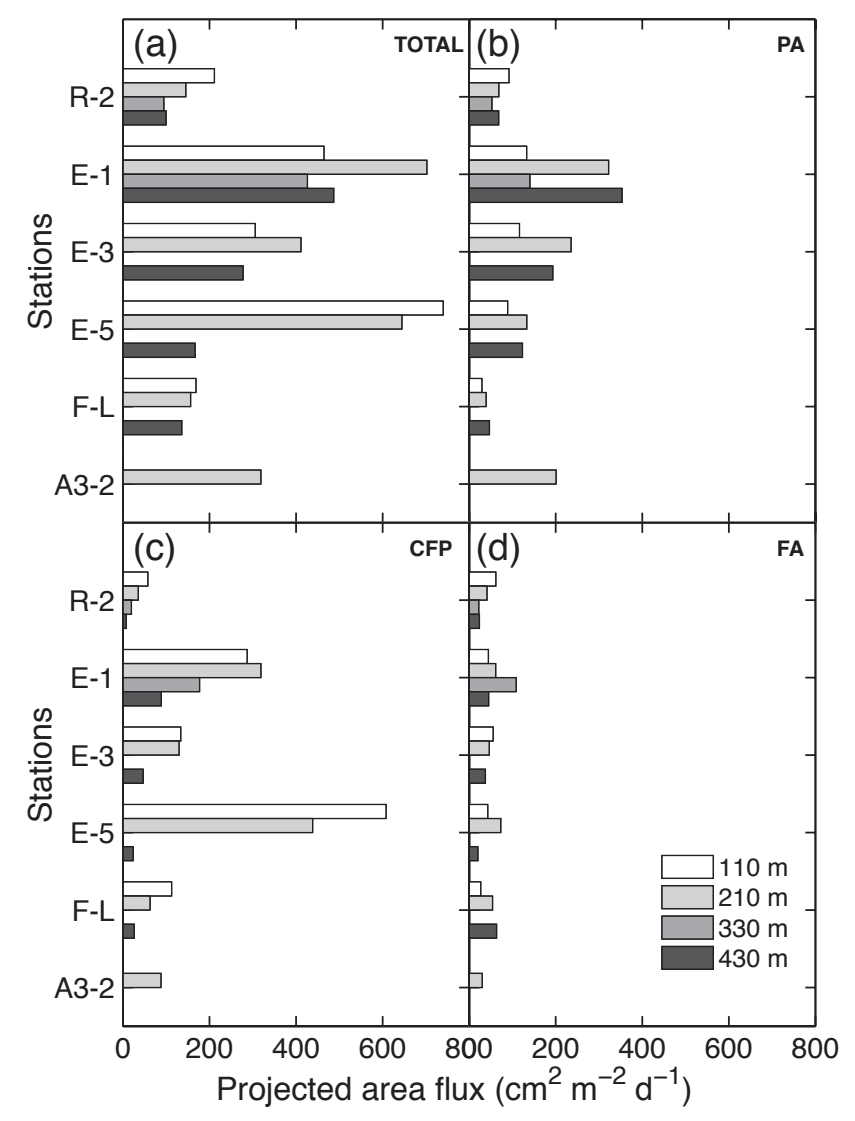

Figure 6. Projected area of particles estimated from image analysis at each site and depth and expressed as fluxes $\left(\mathrm{cm}^{2} \mathrm{~m}^{-2} \mathrm{~d}^{-1}\right)$. (a) All particles (TOTAL), (b) phytodetrital aggregates (PA), (c) cylindrical fecal pellets (CFP) and (d) fecal aggregates (FA). The figure suggests a sinking flux dominated by cylindrical fecal pellets at the surface, except at R-2, where phytodetrital aggregates represented the most important fraction. The attenuation of the cylindrical fecal pellet flux with depth observable at all stations was combined with an increase in the flux of phytodetrital and fecal aggregates at almost all stations. At $430 \mathrm{~m}$, phytodetrital aggregates were then the most dominant particles.

gregates brought the largest fractional contribution with 63, 47 and $55 \%$ at R-2, E-1 and E-5 respectively. Fecal aggregates generally carried a small fraction of the carbon flux, with an average of $13 \pm 8 \%$ (all stations and depths), but their contribution tended to increase with depth (e.g. 24 and $33 \%$ at $430 \mathrm{~m}$ at R-2 and F-L respectively).

\subsection{Biogeochemical fluxes collected in PPS3/3 traps}

Bulk fluxes from PPS3/3 traps are reported in Table 4. The highest mass, POC, ${ }^{234} \mathrm{Th}$ and TPN fluxes were collected at $\mathrm{E}$ stations. POC fluxes decreased over time from $84 \pm 27$ at E-1, to $58 \pm 18$ at E-3, to $24 \pm 12$ at E- $5 \mathrm{mg} \mathrm{C} \mathrm{m}^{-2} \mathrm{~d}^{-1}$. A3-2 presented a POC flux of $27 \mathrm{mg} \mathrm{C} \mathrm{m}^{-2} \mathrm{~d}^{-1}$. An average ${ }^{234} \mathrm{Th}$ activity of $988 \pm 127 \mathrm{dpm} \mathrm{m}^{-2} \mathrm{~d}^{-1}$ was recorded at $\mathrm{E}$ stations, with a maximum of $1129 \pm 177 \mathrm{dpm} \mathrm{m}^{-2} \mathrm{~d}^{-1}$ at E-
3. ${ }^{234}$ Th fluxes are detailed in Planchon et al. (2014). Over all sites, BSi fluxes were very high $(7 \pm 2$ to $21 \pm 10 \mathrm{mmol}$ BSi $\mathrm{m}^{-2} \mathrm{~d}^{-1}$ ), suggesting the large contribution of diatoms to the phytoplankton community. Conversely, very low particulate inorganic carbon (PIC) fluxes (1-4 orders of magnitude lower than POC fluxes) suggested the limited role of calcium carbonate $\left(\mathrm{CaCO}_{3}\right)$ in biogenic mineral fluxes. POC:TPN ratios were close to the canonical Redfield ratio of 6.6 for phytoplankton at all stations except E-5 (7.5), which also displayed the lowest POC: BSi ratio (0.1). At E stations, POC: ${ }^{234} \mathrm{Th}$ and POC : mass ratios decreased over time (POC: ${ }^{234} \mathrm{Th}$ ratios from 8 at E-1 to $2.1 \mu \mathrm{mol} \mathrm{\textrm {dpm } ^ { - 1 }}$ at E-5; POC: mass ratio from 0.05 at E-1 to $0.03 \mathrm{gg}^{-1}$ at E-5), suggesting an attenuation of export fluxes combined with a degradation of sinking particles. A3-2 displayed POC : ${ }^{234} \mathrm{Th}$ and POC: mass ratios of $4.4 \mu \mathrm{moldpm}^{-1}$ and $0.06 \mathrm{~g} \mathrm{~g}^{-1}$ respectively. In general, no consistent differences in fluxes could be resolved between poisoned and unpoisoned cups.

\subsection{POC flux comparisons and export efficiencies}

POC fluxes determined from gel images (using particle volume-to-carbon-content conversion factors) were in the same range of values as those determined from particle collection in PPS3/3, with maximum differences at a same station never exceeding 1 order of magnitude (Tables 3 and 4). POC fluxes from PPS $3 / 3$ were systematically lower than those derived from image analysis (on average $57 \pm 22 \%$ less).

E-ratios, calculated as the ratio of POC fluxes from gel image analysis to $1 \%$ PAR-integrated net primary productivity (Cavagna et al., 2014; Table 5) indicated a high export efficiency at R-2 and E-1 (0.2 \pm 0.08 and $0.23 \pm 0.07$ respectively, all depths averaged), intermediate at E-3 and E-5 $(0.1 \pm 0.02$ and $0.13 \pm 0.09$ respectively, all depths averaged), and very low at F-L $(0.01 \pm 0.0$, similar value at all depths $)$ and A32 (0.03). E-ratios derived from POC fluxes estimated from PPS3/3 traps showed lower values but followed the same trend: E-1 > E-3 > E-5 > A3-2. Export efficiencies derived from ${ }^{234} \mathrm{Th}$ disequilibria, $\mathrm{ThE}_{\mathrm{C}}$ (Planchon et al., 2014), are shown in Table 5 for comparison, and are discussed in the next section.

According to calculations based on gel trap POC flux and transmissometer POC concentration estimates (Fig. 2), E stations exported the largest percentage of their mixed-layerintegrated POC $\left(\Sigma \mathrm{POC}_{\mathrm{ML}}\right)$ per day $(2.4 \pm 1 \%$, all $\mathrm{E}$ stations and depths averaged) with the maximum observed at E-5 $(2.7 \pm 1.8 \%$, all depths averaged) and values of $2.3 \pm 0.7$ and $2.3 \pm 0.5 \%$ at E-1 and E-3 respectively (all depths averaged). R-2 and F-L exported respectively $0.58 \pm 0.2$ and $0.59 \pm 0.15 \%$ of their $\Sigma$ POC $\mathrm{ML}$ per day (all depths averaged), and $\mathrm{A} 3-2$ exported $0.32 \%$ of its $\Sigma$ POC $\mathrm{ML}_{\mathrm{ML}}$ per day $(210 \mathrm{~m})$. A similar trend was obtained using POC fluxes from PPS3/3 traps (E stations $>$ A3-2). 


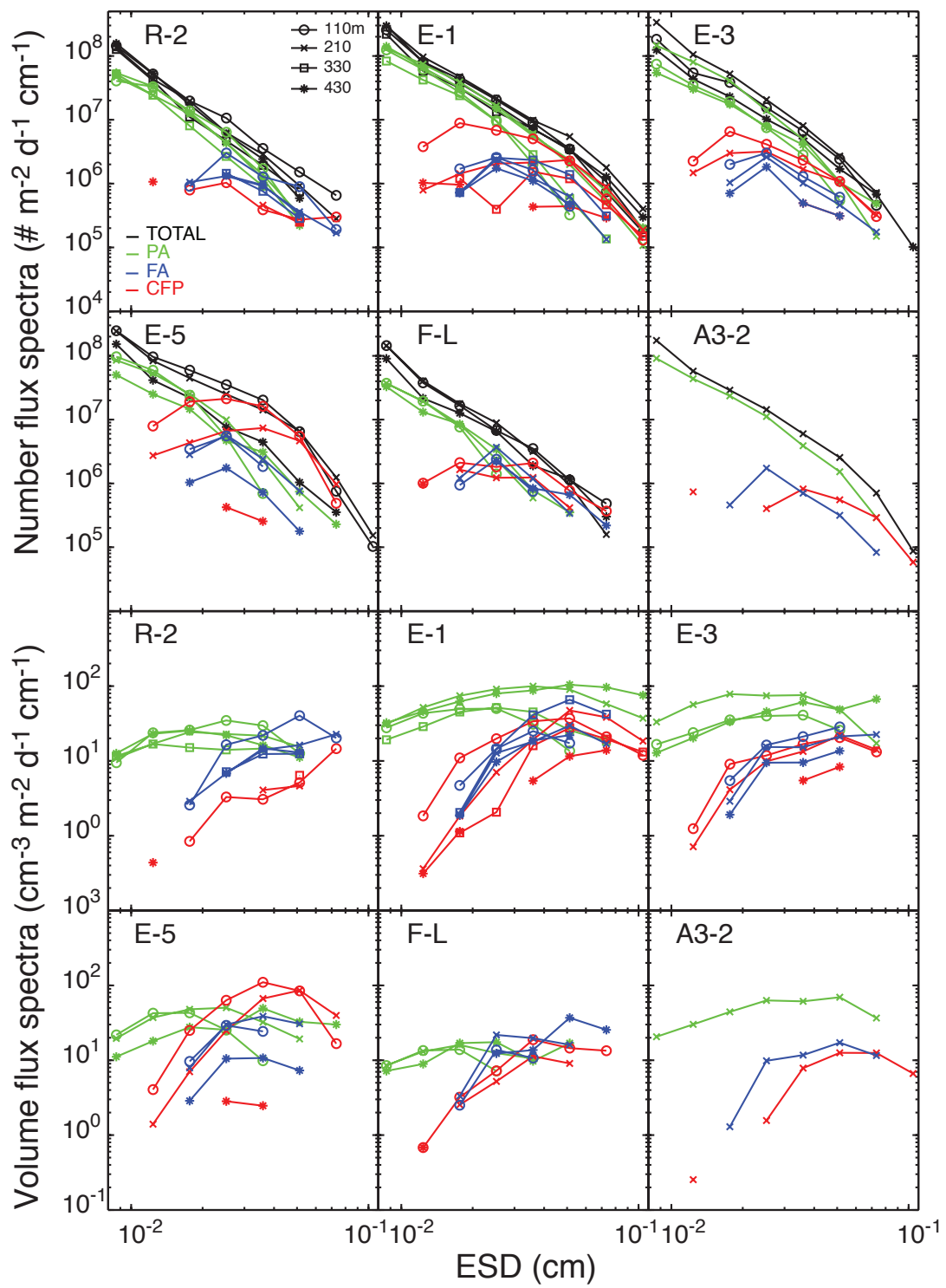

Figure 7. Total number and volume fluxes of particles binned in 10 size classes. Bins with less than five particles were removed (see Table 2 and text for explanations). Results are shown for each category of particles at all depths and sites. TOTAL: all particles; PA: phytodetrital aggregates; FA: fecal aggregates; CFP: cylindrical fecal pellets. Smallest particles represented by phytodetrital aggregates were the most numerous at every site and depth. Middle-sized phytodetrital aggregates and fecal particles (pellets and aggregates) contributed the most to the volume flux due to the overall rarity of very large particles relative to all particles.

\section{Discussion}

\subsection{Comparison of POC flux estimations}

Two different approaches were used to estimate POC fluxes. PPS $3 / 3$ trap collection providing a direct determination of the flux served as a reference method. POC fluxes estimated from image analysis of particles embedded in polyacrylamide gels were in the same range as those derived from PPS3/3 but were systematically higher (see Sect. 3). This difference is most likely due to the uncertainty in the volume-to-carbon conversion factors (Fig. 4) used to esti- mate POC fluxes from particle image analysis. A comparison with the direct estimation of bulk fluxes collected in PPS3/3 suggests that our volume-to-carbon-content conversion factors tended to slightly overestimate the carbon carried by sinking particles (Tables 3 and 4), especially at E-5, where it was up to 7-fold higher. At this station the large contribution of cylindrical fecal pellets to the volume flux (Table 3; $72 \%$ at $110 \mathrm{~m}$ and $51 \%$ at $210 \mathrm{~m}$ ) suggests that the volume-to-carbon conversion factor used for these particles may be responsible for the mismatch observed. The value of $0.036 \mathrm{mg} \mathrm{Cmm}^{-3}$ used as an average for copepod and euphausiid fecal pellets may not reflect the actual carbon con- 
Table 4. Particle fluxes at $210 \mathrm{~m}$ depth from free-drifting deployments of the 12-cup-carousel cylindrical PPS $3 / 3$ trap. The trap collection area was $0.125 \mathrm{~m}^{2}$. Particles were washed through a $350 \mu \mathrm{m}$ Nitex screen to remove zooplankton and were collected on a $1 \mathrm{~mm}$ silver filter. Mean values and their standard deviations are indicated in bold.

\begin{tabular}{|c|c|c|c|c|c|c|c|c|c|c|c|c|c|}
\hline \multirow[t]{2}{*}{$\begin{array}{l}\text { Cup } \\
\text { ID \# }\end{array}$} & Opening time $(\mathrm{UTC})^{\mathrm{a}}$ & $\begin{array}{l}\text { Poison } \\
\text { in cup }\end{array}$ & Mass flux & POC flux & TPN flux & BSi flux & PIC flux & ${ }^{234}$ Th flux & POC:TPN & POC: $\mathrm{BSi}$ & POC:PIC & POC: ${ }^{234} \mathrm{Th}$ & POC: mass \\
\hline & [duration (h)] & & $\left(\mathrm{g} \mathrm{m}^{-2} \mathrm{~d}^{-1}\right)$ & $\left(\mathrm{mgCm}^{-2} \mathrm{~d}^{-1}\right)$ & \multicolumn{3}{|c|}{$\left(\mathrm{mmolm} \mathrm{m}^{-2} \mathrm{~d}^{-1}\right)$} & $\left(\mathrm{dpmm}^{-2} \mathrm{~d}^{-1}\right)$ & \multicolumn{3}{|c|}{$\left(\mathrm{mol} \mathrm{mol}^{-1}\right)$} & $\left(\mu \mathrm{moldpm}{ }^{-1}\right)$ & $\left(\mathrm{gg}^{-1}\right)$ \\
\hline \multicolumn{14}{|l|}{ E-1 } \\
\hline 1 & 29 Oct 11, 13:00 [12] & none & - & - & - & - & - & - & - & - & - & - & - \\
\hline 2 & 30 Oct $11,01: 00[12]$ & none & - & - & - & - & - & - & - & - & - & - & - \\
\hline 3 & 30 Oct $11,13: 00[12]$ & $\mathrm{HgCl}_{2}$ & 2.55 & 120.10 & 1.46 & 34 & 0.01 & 722 & 6.84 & 0.29 & 1016 & 13.8 & 0.05 \\
\hline 4 & 31 Oct $11,01: 00[12]$ & $\mathrm{HgCl}_{2}$ & 2.34 & 103.17 & 1.22 & 32 & 0.00 & 675 & 7.04 & 0.27 & 88092 & 12.7 & 0.04 \\
\hline 5 & 31 Oct $11,13: 00[12]$ & none & - & - & - & - & - & - & - & - & - & - & - \\
\hline 6 & 1 Nov 11, 01:00 [12] & none & - & - & - & - & - & - & - & - & - & - & - \\
\hline 7 & 1 Nov $11,13: 00[12]$ & none & 1.14 & 64.73 & 0.71 & 11 & 0.83 & 869 & 7.56 & 0.51 & 6.53 & 6.2 & 0.06 \\
\hline 8 & 2 Nov 11, 01:00 [12] & none & 1.06 & 43.24 & 0.60 & 11 & 0.58 & 826 & 5.99 & 0.34 & 6.21 & 4.4 & 0.04 \\
\hline 9 & $2 \operatorname{Nov} 11,13: 00[12]$ & none & - & - & - & - & - & - & - & - & - & - & - \\
\hline 10 & 3 Nov $11,01: 00[12]$ & none & 1.72 & 90.44 & 1.10 & 17 & 0.67 & 1311 & 6.87 & 0.44 & 11.30 & 5.7 & 0.05 \\
\hline 11 & $3 \operatorname{Nov} 11,01: 00[\mathrm{Blk}]$ & none & - & - & - & - & - & - & - & - & - & - & - \\
\hline \multirow[t]{3}{*}{12} & $3 \operatorname{Nov} 11,01: 00[B 1 k]$ & none & - & 0 & 0.00 & - & 0.00 & - & 3.86 & - & 11.60 & - & - \\
\hline & & mean $^{\mathrm{b}}$ & 1.76 & 84.31 & 1.02 & 21.03 & 0.52 & 881 & 6.90 & 0.33 & 13.49 & 8.6 & 0.05 \\
\hline & & $\mathbf{S D}^{\mathrm{c}}$ & 0.61 & 27.38 & 0.32 & 10.41 & 0.31 & 226 & 0.57 & 0.10 & NA & 3.9 & 0.01 \\
\hline \multicolumn{14}{|l|}{ E-3 } \\
\hline 1 & 5 Nov 11, 07:00 [1] & none & - & - & - & - & - & - & - & - & - & - & - \\
\hline 2 & 5 Nov $11,08: 00[8]$ & none & - & - & - & - & - & - & - & - & - & - & - \\
\hline 3 & $5 \operatorname{Nov} 11,09: 00[1]$ & $\mathrm{HgCl}_{2}$ & 1.34 & 40.95 & 0.38 & 10 & 0.39 & 997 & 8.89 & 0.33 & 8.69 & 3.4 & - \\
\hline 4 & 5 Nov $11,17: 00[8]$ & $\mathrm{HgCl}_{2}$ & 0.99 & 45.64 & 0.55 & 11 & 0.60 & 1073 & 6.89 & 0.36 & 6.38 & 3.5 & 0.05 \\
\hline 5 & 6 Nov $11,01: 00[12]$ & none & - & - & - & - & - & - & - & - & - & - & - \\
\hline 6 & 6 Nov 11, 13:00 [12] & none & - & - & - & - & - & - & - & - & - & - & - \\
\hline 7 & 7 Nov $11,01: 00[12]$ & none & 1.11 & 35.07 & 0.45 & 9 & 1.11 & 947 & 6.43 & 0.31 & 2.62 & 3.1 & 0.03 \\
\hline 8 & 7 Nov $11,13: 00[12]$ & none & 0.97 & 28.10 & 0.38 & 8 & 1.01 & 813 & 6.14 & 0.28 & 2.31 & 2.9 & 0.03 \\
\hline 9 & $8 \operatorname{Nov} 11,01: 00[12]$ & none & - & - & - & - & - & - & - & - & - & - & - \\
\hline 10 & 8 Nov $11,13: 00[12]$ & none & - & - & - & - & - & - & - & - & - & - & - \\
\hline 11 & 9 Nov $11,01: 00[12]$ & $\mathrm{HgCl}_{2}$ & 1.21 & 64.13 & 0.71 & 11 & 0.71 & 1240 & 7.47 & 0.49 & 7.53 & 4.3 & 0.05 \\
\hline \multirow[t]{3}{*}{12} & 9 Nov 11, 13:00 [12] & $\mathrm{HgCl}_{2}$ & 2.17 & 116.50 & 1.48 & 22 & 1.19 & 1565 & 6.55 & 0.44 & 8.14 & 6.2 & 0.05 \\
\hline & & mean & 1.35 & 58.49 & 0.72 & 12.35 & 0.94 & 1129 & 6.74 & 0.39 & 5.19 & 4.02 & 0.04 \\
\hline & & SD & 0.46 & 18.50 & 0.21 & 2.48 & 0.20 & 177 & 1.01 & 0.08 & 2.80 & 1.24 & 0.01 \\
\hline \multicolumn{14}{|l|}{ E-5 } \\
\hline 1 & 18 Nov $11,13: 00[3]$ & none & - & - & - & - & - & - & - & - & - & - & - \\
\hline 2 & 18 Nov $11,16: 00[3]$ & none & - & - & - & - & - & - & - & - & - & - & - \\
\hline 3 & 18 Nov $11,19: 00[3]$ & $\mathrm{HgCl}_{2}$ & - & - & - & - & - & - & - & - & - & - & - \\
\hline 4 & 18 Nov $11,22: 00[3]$ & $\mathrm{HgCl}_{2}$ & 1.6 & 40.83 & 0.4 & 32 & 0.8 & 1688 & 7.79 & 0.11 & 4.39 & 2.0 & 0.03 \\
\hline 5 & 19 Nov $11,01: 00[3]$ & none & - & - & - & - & - & - & - & - & - & - & - \\
\hline 6 & 19 Nov $11,04: 00[3]$ & none & - & - & - & - & - & - & - & - & - & - & - \\
\hline 7 & 19 Nov $11,07: 00[3]$ & none & - & - & - & - & - & - & - & - & - & - & - \\
\hline 8 & 19 Nov $11,10: 00[3]$ & none & 0.42 & 16.81 & 0.2 & 6 & 0.4 & 378 & 6.83 & 0.25 & 3.34 & 3.8 & 0.04 \\
\hline 9 & 19 Nov $11,13: 00[3]$ & none & - & - & - & - & - & - & - & - & - & - & - \\
\hline 10 & 19 Nov $11,16: 00[3]$ & none & - & - & - & - & - & - & - & - & - & - & - \\
\hline 11 & 19 Nov $11,19: 00[3]$ & $\mathrm{HgCl}_{2}$ & 0.29 & 14.41 & 0.2 & 5 & 0.2 & 800 & 7.41 & 0.22 & 6.37 & 1.4 & 0.05 \\
\hline \multirow[t]{3}{*}{12} & $19 \operatorname{Nov} 11,19: 00$ [n.r.] & - & - & - & - & - & - & - & - & - & - & - & - \\
\hline & & mean & 0.78 & 24.02 & 0.27 & 14.25 & 0.46 & 955 & 7.46 & 0.14 & 4.32 & 2.42 & 0.03 \\
\hline & & SD & 0.60 & 12.01 & 0.12 & 12.41 & 0.24 & 546 & 0.48 & 0.08 & 1.54 & 1 & 0.01 \\
\hline \multicolumn{14}{|l|}{ A3-2 } \\
\hline 1 & $15 \operatorname{Nov} 11,22: 00[3]$ & none & - & - & - & - & - & - & - & - & - & - & - \\
\hline 2 & 16 Nov $11,01: 00[3]$ & none & - & - & - & - & - & - & - & - & - & - & - \\
\hline 3 & 16 Nov $11,04: 00[3]$ & $\mathrm{HgCl}_{2}$ & - & - & - & - & - & - & - & - & - & - & - \\
\hline 4 & $16 \operatorname{Nov} 11,07: 00[3]$ & $\mathrm{HgCl}_{2}$ & 0.42 & 19.34 & 0.22 & 6 & 0.19 & 498 & 7.19 & 0.29 & 8.32 & 3.2 & 0.05 \\
\hline 5 & $16 \operatorname{Nov} 11,10: 00[3]$ & none & - & - & - & - & - & - & - & - & - & - & - \\
\hline 6 & $16 \operatorname{Nov} 11,13: 00[3]$ & none & - & - & - & - & - & - & - & - & - & - & - \\
\hline 7 & 16 Nov $11,16: 00[3]$ & none & - & - & - & - & - & - & - & - & - & - & - \\
\hline 8 & 16 Nov $11,19: 00[3]$ & none & 0.42 & 22.94 & 0.30 & 6 & 0.27 & 535 & 6.36 & 0.34 & 7.19 & 3.6 & 0.05 \\
\hline 9 & $16 \operatorname{Nov} 11,22: 00[3]$ & none & - & - & - & - & - & - & - & - & - & - & - \\
\hline 10 & $16 \operatorname{Nov} 11,01: 00[3]$ & none & - & - & - & - & - & - & - & - & - & - & - \\
\hline 11 & 17 Nov $11,04: 00[3]$ & $\mathrm{HgCl}_{2}$ & - & - & - & - & - & - & - & - & - & - & - \\
\hline \multirow[t]{3}{*}{12} & 17 Nov $11,07: 00[3]$ & $\mathrm{HgCl}_{2}$ & 0.42 & 38.19 & 0.55 & 10 & 0.28 & 486 & 5.79 & 0.31 & 11.51 & 6.5 & 0.09 \\
\hline & & mean & 0.42 & 26.78 & 0.36 & 7.17 & 0.25 & 506 & 6.24 & 0.31 & 9.11 & 4.45 & 0.06 \\
\hline & & SD & 0.00 & 8.17 & 0.14 & 2.24 & 0.04 & 21 & 0.71 & 0.02 & 2.24 & 1.48 & 0.02 \\
\hline
\end{tabular}

a Local time was UTC $+5 \mathrm{~h}$.
$\mathrm{b}$ For all stations, mean values are the total collection divided by the total time over the entire deployment. ${ }^{\mathrm{c}}$ For all stations, flux standard deviations are weighted by cup duration times. Component ratio standard deviations are unweighted. n.r.: not rotated.
NA: not available.

NA: not avai
Blk: blank.

tained in the cylindrical fecal pellets collected. Feeding behaviours (e.g. herbivorous or coprophagous) specific to each zooplankton group will produce fecal pellets with variable carbon content due to variable fraction of undigested food, compaction or vulnerability to physical or biological degradation (Urban-Rich et al., 1998). Constant carbon to volume ratios are thus unable to reflect the myriad of fecal pellet compositions linked to ecosystem structure variations. Values of carbon content in cylindrical fecal pellets found in the literature range over approximately 1 order of magnitude between 0.01 and $0.1 \mathrm{mg} \mathrm{C} \mathrm{mm}^{-3}$ (González and Smetacek, 1994; González et al., 1994, 2000; Carroll et al., 1998), leading to potential strong variations in carbon flux estimations if large volumes of fecal pellets are involved, as was the case at 
Table 5. Export efficiency at each site estimated from several methods. Maximum and minimum export efficiencies are indicated in bold.

\begin{tabular}{|c|c|c|c|c|c|c|}
\hline \multirow{2}{*}{$\begin{array}{l}\text { Site } \\
\text { ID }\end{array}$} & \multirow{2}{*}{$\begin{array}{c}\text { Depth } \\
\text { (m) }\end{array}$} & \multicolumn{2}{|c|}{ E-ratios } & \multirow[t]{2}{*}{$\mathrm{ThE}_{\mathrm{C}}$} & \multicolumn{2}{|c|}{$\% \sum$ POC $_{\mathrm{ML}}$ export $1 \mathrm{~d}$} \\
\hline & & Gels & PPS3/3 & & Gels & PPS $3 / 3$ \\
\hline \multirow[t]{4}{*}{$\mathrm{R}-2$} & $100 \pm 10$ & 0.32 & - & 0.34 & 0.92 & - \\
\hline & $200 \pm 10$ & 0.22 & - & 0.16 & 0.64 & - \\
\hline & 330 & 0.15 & - & - & 0.43 & - \\
\hline & 430 & 0.12 & - & - & 0.34 & - \\
\hline \multirow[t]{4}{*}{ E-1 } & $100 \pm 10$ & 0.21 & - & 0.27 & 2.12 & - \\
\hline & $200 \pm 10$ & 0.34 & $\mathbf{0 . 1 6} \pm 0.05$ & 0.18 & 3.34 & $1.59 \pm 0.52$ \\
\hline & 330 & 0.21 & - & - & 2.05 & - \\
\hline & 430 & 0.18 & - & - & 1.82 & - \\
\hline \multirow[t]{3}{*}{ E-3 } & $100 \pm 10$ & 0.10 & - & 0.21 & 2.22 & - \\
\hline & $200 \pm 10$ & 0.12 & $0.08 \pm 0.03$ & 0.14 & 2.82 & $1.92 \pm 0.64$ \\
\hline & 430 & 0.08 & - & - & 1.86 & - \\
\hline \multirow[t]{3}{*}{ E-5 } & $100 \pm 10$ & 0.19 & - & 0.11 & 3.76 & - \\
\hline & $200 \pm 10$ & 0.19 & $0.03 \pm 0.02$ & 0.1 & 3.69 & $0.50 \pm 0.25$ \\
\hline & 430 & 0.03 & - & - & 0.63 & - \\
\hline \multirow[t]{3}{*}{ F-L } & $100 \pm 10$ & 0.01 & - & 0.01 & 0.73 & - \\
\hline & $200 \pm 10$ & 0.01 & - & 0.01 & 0.62 & - \\
\hline & 430 & 0.01 & - & - & 0.42 & - \\
\hline \multirow[t]{2}{*}{ A3-2 } & $100 \pm 10$ & - & - & 0.05 & - & - \\
\hline & $200 \pm 10$ & 0.03 & $\mathbf{0 . 0 1} \pm 0.004$ & 0.02 & 0.32 & $0.13 \pm 0.04$ \\
\hline
\end{tabular}

E-ratio: POC flux (gels, PPS3/3) / NPP (EZ integration $1 \%$ PAR; data from Cavagna et al., 2014). $\mathrm{ThE}_{\mathrm{C}}$ : POC flux $\left({ }^{234} \mathrm{Th}\right.$; data from Planchon et al., 2014)/NPP

$\% \sum$ POC $_{\mathrm{ML}}$ export $1 \mathrm{~d}$ : percentage of mixed-layer-integrated POC exported in 1 day.

E-5. Mesozooplankton communities collected in Bongo nets from $250 \mathrm{~m}$ to the surface (day and night haulings, except at R-2 and F-L, where only day haulings were conducted), and analysed with a ZooScan integrated system (Carlotti et al., 2015), generally revealed a large dominance of the size fraction 500-1000 $\mu \mathrm{m}$ with values from 54 to $79 \%$ (considering only the stations where the traps were deployed). Microscopic identifications confirmed a community largely dominated by copepods (Carlotti et al., 2015). However, most of the fecal pellets collected in gel traps at E-5 were large fragments (Fig. 5), with a peritrophic membrane interrupted at their extremities suggesting more probably an origin from euphausiids rather than copepods, which produce smaller fecal pellets with a continuous peritrophic membrane terminated by a pellicle (Gauld, 1957; Martens, 1978; Yoon et al., 2001). Differences in euphausiid and copepod fecal pellet sinking velocities due to size variations, ballast content or compaction (Fowler and Small, 1972; Small et al., 1979), as well as contrasted sensitivities to degradation or zooplankton vertical migration behaviours (Wallace et al., 2013), could explain the mismatch between the zooplankton community identified from net haulings and the fecal pellets collected in gel traps. A reduced collection efficiency of euphausiids compared to copepods could also be responsible for this mismatch, knowing that specific nets like the Multiple Opening and Closing Nets and Environment Sensing System (MOCNESS; Wiebe et al., 1976) are needed to efficiently capture both mesozooplankton and euphausiids in the layer 0-250 m (e.g. Espinasse et al., 2012). Most studies show that zoo- plankton net avoidance is complex and variable; it depends on environmental conditions (e.g. light regime), net characteristics, and various zooplankton characteristics, including size, shape, species, sex and developmental stage (Brinton, 1967; Fleminger and Clutter, 1965; Wiebe et al., 1982).

Assuming a dominance of euphausiid fecal pellets at E-5, the use of the reference value of $0.016 \mathrm{mg} \mathrm{C} \mathrm{mm}^{-3}$ improves the match between POC fluxes estimated from PPS3/3 and gel traps (ratios $\mathrm{POC}_{\text {gels }} / \mathrm{POC}_{\mathrm{PPS} 3 / 3}=4$ ), although it cannot fully explain the discrepancy, presumably due to other factors (e.g. particle field heterogeneity or small differences in sediment trap collection efficiencies).

\subsection{Evolution of the flux at depth}

POC fluxes presented in Fig. 8 were estimated through two different approaches: gel trap image analysis (at 110, 210, 330 and $430 \mathrm{~m}$ ) and total ${ }^{234} \mathrm{Th}$ activity measured at $11-$ 14 depths at all stations (Planchon et al., 2014) and calculated at 100, 150 and $200 \mathrm{~m}$. Fluxes estimated from PPS3/3 trap collection at only one depth $(210 \mathrm{~m})$ are not presented here. Figure 8 shows the evolution of POC fluxes with depth and its comparison with the empirical flux attenuation known as the "Martin curve" (Martin et al., 1987), estimating the flux at depth from values at $100 \mathrm{~m}$ ranging from 20 to $500 \mathrm{mg} \mathrm{C} \mathrm{m}^{-2} \mathrm{~d}^{-1}$. Agreements between POC flux determination methods and this empirical relationship were the best for R-2 and F-L, showing a continuous attenuation of the flux with depth, but always at a lower rate than predicted by the Martin curve.

For all other stations POC fluxes above $210 \mathrm{~m}$ presented complex patterns suggesting distinct POC export episodes to be more likely than a continuous downward flux. Between 210 and $430 \mathrm{~m}$ the attenuation of POC fluxes estimated from the gel traps tends to be more consistent with the Martin curve, except for E-5, which displayed a strong decrease (as already noted in the Sect. 3). A fecal pellet loss at depth was particularly strong at E-5, due to the large role played by these particles at this site, but was observed at all stations (Fig. 6).

Our data revealed two major trends of particle flux evolution with depth: (i) the fecal pellet flux decreased, and (ii) phytodetrital and fecal aggregate fluxes remained constant or even increased. Establishing a link between these two processes is tempting. It suggests the importance of physical reaggregation in sustaining the carbon flux at depth from fecal pellets that have undergone bacterial degradation or zooplankton coprorhexy (Suzuki et al., 2003; Lampitt et al., 1990; Iversen and Poulsen, 2007). A recent study from Giering et al. (2014) suggests that half of fast-sinking particles in the twilight zone of the eastern Atlantic Ocean (between 50 and $1000 \mathrm{~m}$ ) are fragmented and ingested by zooplankton, and that more than $30 \%$ may be released as suspended and slowly sinking organic matter. Even if the gel trap technique does not offer enough information on 


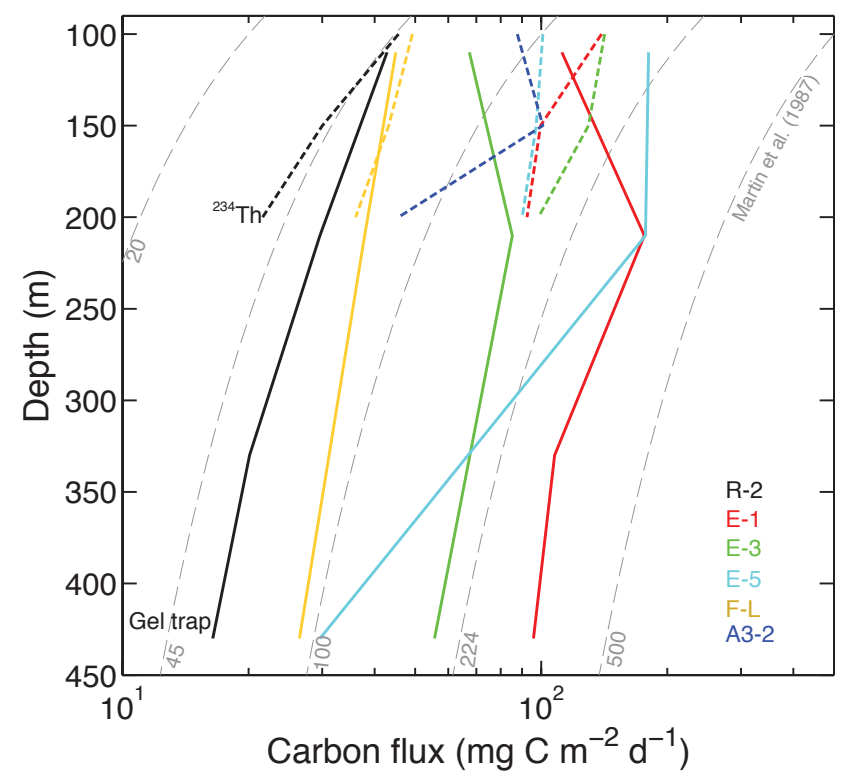

Figure 8. Variation in the carbon flux with depth estimated from gel trap and ${ }^{234} \mathrm{Th}$ methods. The empirical attenuation of the flux with depth (Martin curve) is represented by grey dashed lines for initial values of the carbon flux at $100 \mathrm{~m}$ from 20 to $500 \mathrm{mg} \mathrm{Cm}^{-2} \mathrm{~d}^{-1}$. Results show overall poor agreements between observed fluxes and the Martin curve, suggesting the complexity of the processes affecting the carbon flux with depth.

aggregation processes and particle sources to permit any clear conclusion, the hypothesis of a reaggregation of unpacked fecal pellets into "secondary" phytodetrital aggregates still deserves careful consideration.

Since the rate of physical aggregation is largely controlled by particle concentration (Jackson, 1990), a reaggregation at depth implies that sufficient material has been released by fecal pellet disaggregation. If single cells represented most of the material released during fecal pellet disaggregation, their concentration should have increased with depth in the case of no secondary aggregation or remained constant as a balance between aggregate formation and loss by sinking (notion of critical concentration; Jackson, 1990, 2005). The number flux spectra (Fig. 7) suggest that the smallest particles had a constant concentration until $210 \mathrm{~m}$ at almost every site. Station E-3 shows an increase in the number of small particles between 110 and $210 \mathrm{~m}$ and then a decrease at $430 \mathrm{~m}$, which could indicate reaggregation processes occurring at depth. This decrease at $430 \mathrm{~m}$ is also observable at E-5 and F-L. However, data evaluation in this way implies a steady-state assumption which considers that traps measured the occurrence of a unique sinking event; the flux collected at depth being a direct temporal evolution of the same shallower flux. This appears unlikely considering the episodic nature of export and its dependence on highly dynamical ecosystem interactions responsible for high flux variability at short spatiotemporal scales as evidenced by the PPS $3 / 3$ individual cup
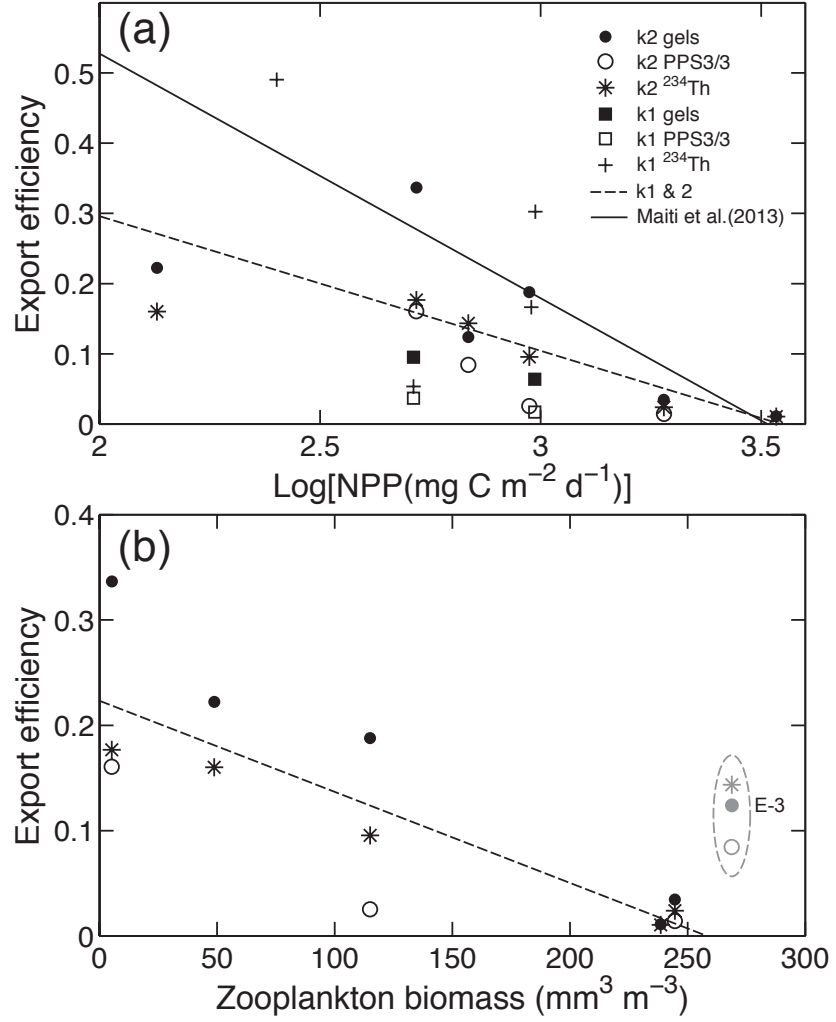

Figure 9. Relationships between net primary productivity (a), zooplankton biomass (b) and export efficiency calculated using particulate organic carbon fluxes estimated at $200 \pm 10 \mathrm{~m}$ from PPS $3 / 3$ traps, gel traps and ${ }^{234} \mathrm{Th}$ methods for the KEOPS2 (k2) and KEOPS1 (k1, (a) only) studies. (a) The black line represents the empirical relationship from Maiti et al. (2013) estimated in the Southern Ocean $\left(y=-0.35 x+1.22 ; r^{2}=0.97\right)$, and the dashed line represents the regression line for all KEOPS data $(y=-0.19 x+0.68$; $\left.n=24, r^{2}=0.33, p<0.005\right)$. (b) The dashed line represents the regression line for KEOPS2 data $(y=-0.00086 x+0.2232 ; n=15$, $\left.r^{2}=0.72, p<0.0005\right)$. E-3 was assumed an outlier and was excluded from the best fit calculation (see text for possible explanation). Panel (a) suggests that the most productive sites are the less efficient to export carbon. Panel (b) suggests that zooplankton biomass could influence the efficiency of carbon export by bypassing direct export via phytodetrital aggregates.

variations (Table 4). In addition, if assuming phytodetrital aggregates at E-3, sinking at an average velocity of $150 \mathrm{md}^{-1}$ (based on results from Laurenceau-Cornec et al., 2015), a particle field would need approximately 1.5 days to sink from 210 to $430 \mathrm{~m}$, neglecting any advection. Considering this calculation and the short trap deployment at E-3 (1.02 days), a non-steady-state assumption appears more reasonable, and the increase in phytodetrital and fecal aggregates observed at depth could reflect an earlier production event. 


\subsection{Temporal POC flux variations during KEOPS2 and comparison with KEOPS1}

From E-1 to E-5, the POC flux varied with the depth and estimation method. Collection of POC flux in PPS3/3 trap at $210 \mathrm{~m}$ revealed a monotonic decrease in the flux with time (Table 4). Temporal evolution of the flux between E-1, E-3 and E-5, at $100 \pm 10$ and $200 \pm 10 \mathrm{~m}$, using gel trap and ${ }^{234} \mathrm{Th}$ methods (Planchon et al., 2014), shows a almost constant flux (undistinguishable differences within the uncertainties). At $430 \mathrm{~m}$, gel traps measured flux evolutions comparable to those identified in the PPS $3 / 3$ at $210 \mathrm{~m}$, i.e. a continuous decrease in the flux with time. With the results from 110 and $210 \mathrm{~m}$ at E-5 excluded (likely linked to an episodic flux of euphausiid fecal pellets at these depths; see text above), the gel traps also show a decrease in the total flux over time, consistent with PPS3/3 trap method. The unusual increase at E-5, against the steady background of the other E stations, highlights the importance of zooplankton in modifying the particle flux.

At the KEOPS1 (January-February 2005) bloom reference station A3, POC flux values estimated at $200 \mathrm{~m}$ from gel trap image analysis and PPS3/3 traps were 62 and 13$20 \mathrm{mg} \mathrm{C} \mathrm{m}^{-2} \mathrm{~d}^{-1}$ respectively (Ebersbach and Trull, 2008), i.e. in the same range as during KEOPS2 at the same station and using the same methods (gels: $66 \mathrm{mg} \mathrm{Cm}^{-2} \mathrm{~d}^{-1}$; PPS3/3: $27 \mathrm{mg} \mathrm{Cm}^{-2} \mathrm{~d}^{-1}$ ). During KEOPS1, the ${ }^{234} \mathrm{Th}-$ based method assuming a non-steady-state system (NSS) yielded $200 \mathrm{~m}$ POC fluxes of $294 \mathrm{mg} \mathrm{Cm}^{-2} \mathrm{~d}^{-1}$ at A3 (flux averaged over 21 days) and $124 \mathrm{mg} \mathrm{Cm}^{-2} \mathrm{~d}^{-1}$ at the KEOPS1 HNLC reference station C11 (flux averaged over 10 days; Savoye et al., 2008). These values are well above the KEOPS2 values of 46 and $22 \mathrm{mg} \mathrm{Cm}^{-2} \mathrm{~d}^{-1}$ determined at $200 \mathrm{~m}$ at A3-2 and R-2 respectively using the same method (average over 28 days, except for R-2 assumed in steady state; Planchon et al., 2014). The ${ }^{234}$ Th-based method assuming NSS integrated the POC flux over a period longer than 20 days, contrasting with the 1 day to 1 week period provided by gel and PPS $3 / 3$ trap estimations.

Seasonal trends are more reliable if calculated over a longer period, and the ${ }^{234} \mathrm{Th}$-based method then gives the best insight into the temporal evolution of the POC flux from the onset of the bloom to its decline. ${ }^{234} \mathrm{Th}$ results suggest that the POC flux was approximately 5- to 6-fold higher at the decline of the bloom (January-February) than during its onset (October-November), agreeing with the common view that most of the export flux occurs in late bloom stage (Wassmann, 1998). During KEOPS1, at A3 and C11, the NPP integrated within the euphotic zone was $1030 \pm 43$ and $224 \pm 30 \mathrm{mg} \mathrm{C} \mathrm{m}^{-2} \mathrm{~d}^{-1}$ respectively (based on ${ }^{13} \mathrm{C}$ incorporation; Mosseri et al., 2008; Lefèvre et al., 2008). In comparison, values of $1903 \pm 186$ and $135 \pm 6 \mathrm{mg} \mathrm{C} \mathrm{m}^{-2} \mathrm{~d}^{-1}$ were determined at A3-2 and R-2 during KEOPS2 (euphotic zone, $\mathrm{E}_{\mathrm{Z}} 1 \%$ PAR-integrated NPP based on ${ }^{13} \mathrm{C}$ incorporation; Cavagna et al., 2014). Carbon export efficiencies estimated at $200 \mathrm{~m}$, based on ${ }^{234} \mathrm{Th}$-derived POC export flux (reported as $\mathrm{ThE}_{\mathrm{C}}$ ), were $30 \%$ at $\mathrm{A} 3$ and $49 \%$ at C11 during KEOPS1 (calculations using data from Savoye et al., 2008; Mosseri et al., 2008). In contrast, $\mathrm{ThE}_{\mathrm{C}}$ values of $2 \%$ (NSS model) and $16 \%$ (SS model) were calculated at $200 \mathrm{~m}$ at A3-2 and R-2 respectively during KEOPS2 (Planchon et al., 2014). These results show that (i) primary productivity at the on-plateau site was approximately 2 -fold higher in spring than during summer and (ii) carbon export fluxes were approximately 5-fold lower during early than late bloom stage, leading to (iii) carbon export efficiencies up to 10-fold lower during the early bloom stage (spring) than during late bloom stage (summer).

\subsection{Toward an explanation of the negative relationship between primary productivity and carbon export efficiency}

We examined two different export efficiency indicators (Table 5): (i) e-ratios calculated as the ratio between POC fluxes estimated from gel images or PPS $3 / 3$ traps, and net primary productivity integrated over the euphotic zone $\left(\mathrm{E}_{\mathrm{Z}} 1 \%\right.$ PAR; Cavagna et al., 2014), and (ii) $\mathrm{ThE}_{\mathrm{C}}$ calculated as the ratio between POC flux estimated from ${ }^{234} \mathrm{Th}$ method and net primary productivity. KEOPS2 results suggest a negative relationship between primary productivity and carbon export efficiency, the most productive sites being those where carbon is exported the least efficiently. Figure 9a shows the relationship between primary productivity and export efficiency (with POC fluxes estimated at $200 \pm 10 \mathrm{~m}$ from gels, PPS $3 / 3$ traps and ${ }^{234} \mathrm{Th}$ water column disequilibria) for KEOPS2 sites. For comparison purposes, KEOPS1 data are also indicated (Savoye et al., 2008). The empirical relationship proposed recently by Maiti et al. (2013), based on surface tethered cylindrical sediment traps and ${ }^{234} \mathrm{Th}$ data from up to 130 stations in the Southern Ocean, is also reported. While this negative relationship has now been observed in several field studies in the Southern Ocean (Savoye et al., 2008; Morris et al., 2007; Jacquet et al., 2011), and elsewhere (e.g. González et al., 2009), the reasons for its existence remain unclear. Maiti et al. (2013) mentioned differences in trophic structure, grazing intensity, recycling efficiency, high bacterial activity, or increase in DOC export as possible explanations for highproductivity, low-export-efficiency regimes. Phytoplankton physiological state has also been suggested as a possible control of carbon export mode and efficiency (González et al., 2009), although this could not be verified here due to a generally good phytoplankton physiological state confirmed via microscopy over the course of the KEOPS2 study (M. Lasbleiz and K. Leblanc, personal communication, 2014). In addition, due to their degradation-resistant and heavily silicified valves (Hargraves and French, 1983; Kuwata and Takahashi, 1990), the abundance of diatom resting spores in the sinking flux, as observed during KEOPS1 (Armand et al., 2008), could also be a major factor to consider when evaluating 
carbon export efficiency as suggested by Salter et al. (2012) and Rynearson et al. (2013).

It was beyond the scope of this study to explore each of these potential controls of carbon export efficiency. However, in the light of KEOPS1 and KEOPS2 results, phytoplankton and zooplankton community structure and their trophic relationships through grazing, seem to have played an important role in carbon export mode and efficiency via controls on sinking particle composition.

Table 6 presents a summary of site characteristics based on net primary productivity, surface plankton communities determined from Niskin bottle sampling and net haulings (most abundant species and biomass), carbon export features at $200 \pm 10 \mathrm{~m}$ (mode and efficiency) and iron fertilisation status (e.g. HNLC or iron-fertilised). Due to their importance in export fluxes demonstrated by high BSi fluxes (see Sect. 3), only diatoms were examined in the phytoplankton community. Data are presented for all stations, but only stations R-2 and A3-2 will be discussed in detail here because of their reference status (i.e. HNLC and on-plateau bloom).

At the HNLC reference station R-2, characterised by the lowest net primary productivity (Cavagna et al., 2014), the diatom community was dominated by the heavily silicified Fragilariopsis spp. (34.6\%: fraction of total live diatom cell counts; see Table 6 for sampling depths; M. Lasbleiz, personal communication, 2014) and Thalassionema nitzschioides $(25.6 \%)$, as well as by a limited mesozooplankton biomass represented mainly by middle-sized copepods (Carlotti et al., 2015). The export was mostly mediated through physical aggregation as suggested by the dominance of phytoplankton and fecal aggregates. The highest eratio estimated during KEOPS 2 was observed at R-2. In contrast, the iron-fertilised on-plateau bloom station A3-2 displayed a high net primary productivity (Cavagna et al., 2014), and a diatom community largely dominated by the lightly silicified Chaetoceros subgenus Hyalochaete (87\%). The mesozooplankton biomass was up to 3-fold higher at A3-2 than at R-2. Small- and middle-sized copepods dominated, along with euphausiid eggs and appendicularians (Carlotti et al., 2015). Particles exported were mostly phytodetrital aggregates. One of the lowest e-ratios was recorded at A3-2. At $\mathrm{E}$ stations, used as a time series, the net primary productivity was moderate (Cavagna et al., 2014), and a shift from a high e-ratio at E-1 to a low e-ratio at E-5 was associated with plankton community shifts. This is indicated, for instance, by the remarkable increase in Chaetoceros subgenus Hyalochaete biomass from 10 and $2.3 \%$ at E-1 and E-3 respectively to $22.5 \%$ at E-5.

At stations R-2 and A3-2, although presenting very contrasted export efficiencies, physical aggregation seemed to dominate over biological aggregation, as suggested by the rarity of fecal pellets. If explained from this perspective, the inverse relationship between net primary productivity and export efficiency somewhat needs to be linked to the different nature of the aggregates produced at each station and their ability to export carbon to depth (e.g. slow- or fastsinking). In parallel with the present study, roller tank experiments have been conducted to explore the influence of different phytoplankton communities on the sinking velocity of large phytodetrital aggregates and their aggregation processes (Laurenceau-Cornec et al., 2015). These experiments consisted in the physical aggregation of natural assemblages sampled with Niskin bottles at high and low biomass sites during KEOPS2. Results suggest that the proportions of different phytoplankton types forming the phytodetrital aggregates could influence their sinking velocity (and potentially their efficiency at exporting carbon) via a control on their structure and excess density. A strong relationship $\left(r^{2}=0.98\right)$ was found between the proportion of small spineforming diatom cells included in marine snow aggregates (e.g. Chaetoceros subgenus Hyalochaete) and their sinking velocity, suggesting an important role for phytoplankton morphology with regard to export efficiency. However, no evidence has been found that natural phytoplankton communities present at each site, as determined from Niskin bottle sampling (Table 6), reflect the composition of their aggregates, something required to approximate their sinking velocity from roller tank experiment results. Experimental and field studies noted that the proportions of diatoms in aggregates are not necessarily the same as their proportions in the surrounding water (Riebesell et al., 1991; Crocker and Passow, 1995; Waite and Nodder, 2001). Without direct estimation of the sinking velocity of natural aggregates formed in the water column at each station, no conclusion is possible and further investigations will be needed.

The potential control of export efficiency through zooplankton grazing is another hypothesis that we explored here. In the case of high grazing pressure, carbon export is driven mostly via fecal pellets, but these, even if sinking fast, potentially experience coprophagy or coprorhexy (Suzuki et al., 2003; Lampitt et al., 1990; Iversen and Poulsen, 2007), and disaggregation processes facilitating bacterial remineralisation (Giering et al., 2014). In Fig. 9b, mesozooplankton biomass data from KEOPS2 $(250 \mathrm{~m}$ to surface Bongo net haulings; Carlotti et al., 2015) is shown as a simple index of zooplankton abundance against export efficiency. Considering all POC flux estimation methods, a correlation has been found ( $\left.n=15, r^{2}=0.72, p<0.0005\right)$, suggesting that zooplankton may exert an important control on export efficiency. In this perspective, however, E-3 presented an unexpectedly high export efficiency considering its high zooplankton biomass, suggesting that factors predominantly affecting carbon export efficiency can vary locally and over time.

In the low-productivity systems (e.g. R-2), a direct export can be efficient if processed via fast-sinking aggregates composed of heavy-silicified diatoms that are also assumed to be grazing-resistant. In contrast, in the sites of high productivity (e.g. A3-2 and F-L), the export flux can be strongly attenuated if a large fraction of the organic carbon flows 
Table 6. Summary of site characteristics based on their primary productivity, plankton communities, iron-fertilisation and carbon export efficiency.

\begin{tabular}{|c|c|c|c|c|c|c|c|}
\hline Site ID & $\begin{array}{l}\mathrm{E}_{Z}-\mathrm{MLD} \\
(\mathrm{m})\end{array}$ & NPP & $\begin{array}{l}\text { Diatom community } \\
\text { (see text for } \% \text { ) }\end{array}$ & $\begin{array}{l}\text { Mesozoo. community }(\%)^{\mathrm{b}} \\
{\left[\text { Total mesozoo. biomass }\left(\mathrm{mm}^{3} \mathrm{~m}^{-3}\right)\right]}\end{array}$ & $\begin{array}{l}\text { Export } \\
\text { mode }\end{array}$ & E-ratio & $\begin{array}{l}\text { Fe source - } \\
\text { biomass/export }\end{array}$ \\
\hline $\mathrm{R}-2$ & $92-96$ & Lowest & $\begin{array}{l}\text { Fragilariopsis spp. } \\
\text { Thalassionema nitzschioides } \\
\text { Centrics }(<25 \mu \mathrm{m})\end{array}$ & $\begin{array}{l}\text { Ctenocalanus citer }(16)+\text { cop. (19) } \\
\text { Oithona frigida }(12) \\
\text { Paraeuchaeta sp. C1-C3 (11) } \\
\text { Rhincalanus gigas C1-C3 (10) [90] }\end{array}$ & PA, FA & Highest & $\begin{array}{l}\text { HNLC - low biomass, high } \\
\text { export efficiency }\end{array}$ \\
\hline E-1 & $64-70$ & Moderate & $\begin{array}{l}\text { Thalassionema nitzschioides } \\
\text { Fragilariopsis spp. } \\
\text { Centrics }(<25 \mu \mathrm{m})\end{array}$ & $\begin{array}{l}\text { Euphausiid eggs (16) } \\
\text { Ctenocalanus citer (5) + cop. (11) } \\
\text { Calanidae C1-C3 (6) [55] }\end{array}$ & CFP, PA & High & \multirow[t]{3}{*}{$\begin{array}{l}\text { Fe-fertilised, mesoscale } \\
\text { recirculation feature - moderate } \\
\text { biomass moderate export efficiency }\end{array}$} \\
\hline E-3 & $68-33$ & Moderate & $\begin{array}{l}\text { Thalassionema nitzschioides } \\
\text { Fragilariopsis spp. }\end{array}$ & $\begin{array}{l}\text { Ctenocalanus citer }(27)+\text { cop. (34) } \\
\text { Oithona frigida (4) }[350]\end{array}$ & CFP, PA & Moderate & \\
\hline E-5 & $54-39$ & Moderate & $\begin{array}{l}\text { Thalassionema nitzschioides } \\
\text { Chaetoceros Hyalochaete spp. } \\
\text { Centrics }(<25 \mu \mathrm{m})\end{array}$ & $\begin{array}{l}\text { Ctenocalanus citer (18) + cop. (18) } \\
\text { Calanidae C1-C3 (15) + cop. (2) } \\
\text { Metridia lucens cop. (6) [203] }\end{array}$ & CFP & Low & \\
\hline F-L & $29-31$ & Highest & $\begin{array}{l}\text { Thalassiosira spp. }(<25 \mu \mathrm{m}) \\
\text { Chaetoceros Hyalochaete } \mathrm{spp} .\end{array}$ & $\begin{array}{l}\text { Euphausiid eggs (26) } \\
\text { Ctenocalanus citer }(11)+\text { cop. (12) } \\
\text { Triconia } \text { sp. (6) }[290]\end{array}$ & CFP, FA & Lowest & $\begin{array}{l}\text { Fe-fertilised, north polar } \\
\text { front mixed zone - high biomass } \\
\text { low export efficiency }\end{array}$ \\
\hline A3-2 & $38-149$ & High & Chaetoceros Hyalochaete spp. & $\begin{array}{l}\text { Euphausiid eggs (19) } \\
\text { Paraeuchaeta } \text { sp. C1-C3 (12) } \\
\text { Appendicularians (12) } \\
\text { Oithona similis }(8) \\
\text { Ctenocalanus citer }(7)+\text { cop. }(8) \text { [310] }\end{array}$ & PA & Low & $\begin{array}{l}\text { Fe-fertilised, } \\
\text { on-plateau bloom site - } \\
\text { high biomass, low export efficiency }\end{array}$ \\
\hline $\begin{array}{l}\text { EZ: depth o } \\
\text { MLD: mixe } \\
\text { NPP: eupho } \\
\text { PA: phytod } \\
\text { CFP: cylind } \\
\text { FA: fecal ag } \\
\text { a Most abur } \\
\text { E-5: } 110 \mathrm{~m} \text {; } \\
\text { b Mesozoof } \\
\text { copepodite }\end{array}$ & $\begin{array}{l}\text { e base of the e } \\
\text { yer depth calc } \\
\text { zone- (1\% PA } \\
\text { al aggregates. } \\
\text { l fecal pellets. } \\
\text { gates. } \\
\text { th diatom gene } \\
\text { : } 52 \mathrm{~m} \text {; A3-2: } \\
\text { kton commun } \\
\text { t } \text { C1-C3: de }\end{array}$ & $\begin{array}{l}\text { tic zone as } \\
\mathrm{d} \text { using the } \\
\text { tegrated } \mathrm{n} \\
\text { species pr } \\
\text { m. See tex } \\
\text { d fraction } \\
\text { ment stage }\end{array}$ & $\begin{array}{l}\text { ed at } 1 \% \text { of the photosynthetic availab } \\
\text { sity difference criterion of } 0.02 \sigma_{\theta} \text { [po } \\
\text { imary productivity (Cavagna et al., } 201 \\
\text { ted in decreasing order of abundance. I } \\
\text { fractions of total live diatom cell count } \\
\text { e total mesozooplankton biomass, pres } \\
3 \text {. }\end{array}$ & $\begin{array}{l}\text { liation (PAR). } \\
\text { al density at MLD = potential density at } 10 \mathrm{~m}+0 \text {. } \\
\text { from M. Lasbleiz (personal communication, 2014 } \\
\text { d by decreasing order of abundance. Data from Ca }\end{array}$ & et al. $(201$ & $\begin{array}{l}\text { al., 1998)]. } \\
\text { from day net }\end{array}$ & $\begin{array}{l}\text { ng depths: R-2: } 116 \mathrm{~m} \text {; E-1: } 80 \mathrm{~m} \text {; E-3: } 137 \mathrm{~m} \text {; } \\
\text { ings only (250 m to the surface). Cop.: }\end{array}$ \\
\hline
\end{tabular}

towards paths promoting its retention in the surface layer (i.e. grazing, microbial remineralisation and biomass accumulation). At A3, Christaki et al. (2014) proposed a carbon budget integrated over the mixed layer showing the carbon flows through microbial and higher trophic levels for early and late bloom stages. This budget indicates that, during KEOPS2, $2400 \mathrm{mg} \mathrm{Cm}^{-2} \mathrm{~d}^{-1}$ was still available for phytoplankton biomass accumulation and/or export after subtracting the different loss terms, such as bacterial, microplankton and mesozooplankton respiration, as well as viral lysis of bacterial cells, from the gross community production (GCP). Using our carbon flux value at $200 \mathrm{~m}$ and phytodetrital aggregate contributions to this export, the relative fractions of the available carbon actually used for biomass accumulation and/or export can be estimated here. At A3-2, the carbon flux at $200 \mathrm{~m}$ was $66 \mathrm{mg} \mathrm{Cm}^{-2} \mathrm{~d}^{-1}$ (gel trap results), with $41 \%$ contributed by phytodetrital aggregates (Table 3). This leads to $27 \mathrm{mg} \mathrm{Cm}^{-2} \mathrm{~d}^{-1}$ exported $(1.1 \%$ of the remaining available carbon) and $2373 \mathrm{mg} \mathrm{C} \mathrm{m}^{-2} \mathrm{~d}^{-1}$ used for biomass accumulation $(98.9 \%)$. The same calculations can be made for the late-bloom situation using the values of $384 \mathrm{mg} \mathrm{C} \mathrm{m}^{-2} \mathrm{~d}^{-1}$ for the carbon still available for biomass accumulation and/or export (Christaki et al., 2014), the KEOPS1 $200 \mathrm{~m}$ POC flux at A3 $\left(62 \mathrm{mg} \mathrm{Cm}^{-2} \mathrm{~d}^{-1}\right.$; Ebersbach and Trull, 2008), and a $36 \%$ aggregate contribution (including both phytodetrital and mixed aggregates; Ebersbach and Trull, 2008). Results lead to $22 \mathrm{mg} \mathrm{Cm}^{-2} \mathrm{~d}^{-1}$ exported $(5.7 \%)$ and $362 \mathrm{mg} \mathrm{Cm}^{-2} \mathrm{~d}^{-1}$ used for biomass accumulation $(94.3 \%)$. These estimations show that the fraction of the carbon available that is exported is subject to large variations during the season (increased by a factor of $\sim 5$ ), while the fraction allocated to biomass accumulation varied comparatively much less (decreased by a factor of $\sim 1.05$ ). This suggests that A3 progressed over the whole season from a retention- to an export-dominated food web system (Wassmann, 1998), possibly related to successions of plankton communities prone to large variations in their export ability, as suggested in this study.

This general picture can be compared with the conceptual scheme of the development of planktonic communities in the Southern Ocean recently proposed by Queguiner (2013). Direct export can occur efficiently when the phytoplankton community is dominated by the large heavily silicified species (e.g. Fragilariopsis spp.), which are highly grazing-resistant and form fast-sinking aggregates. This type of slow-growing species develops through the whole season and forms a "persistent" background encountered at almost all sites. In bloom conditions (during the growth season), smaller fast-growing, lightly silicified species are added to the community, leading to an increased primary productivity. Because these small species are possibly less efficient at exporting carbon (e.g. rapidly grazed and/or sinking slowly), 
the increase in primary productivity is not accompanied by an increase in carbon export - though 2- to 5-fold higher in sites under Fe-fertilisation influence than in the HNLC site required to obtain a high export efficiency.

\section{Conclusions}

Our study conducted in early spring, during bloom initiation, demonstrated the following points:

i. Phytodetrital aggregates represented the main numerical and volume fractions of the flux, especially at depth, and could have played a major role in sustaining export fluxes where fecal pellet flux attenuation occurred. This contrasts with summertime (KEOPS1), when fecal material largely dominated the flux, while phytodetrital aggregates brought only a minor contribution to the flux (Ebersbach and Trull, 2008). However, when converted to carbon content, and where their degradation was limited, cylindrical fecal pellets still represented the dominant fraction of the flux.

ii. Primary productivity was negatively correlated to export efficiency, the sites of highest productivity being the least efficient to export carbon. This supports the emergent vision of high-productivity, low-export regimes already noted in the Southern Ocean (Lam and Bishop, 2007). The decrease in productivity from bloom initiation (KEOPS2) to its decline (KEOPS1), related to a shift from autotroph- to heterotroph-dominated regimes (i.e. production exported via phytodetrital vs. fecal material), could explain why major export tends to occur at the end of the season essentially via the sinking of fecal matter.

iii. Plankton community structure influenced by productivity regimes could have controlled export efficiency via variations in phytoplankton species and zooplankton grazing pressure (Table 6).

Acknowledgements. This work received support through funding from the Australian Commonwealth Cooperative Research Centres Program to the ACE CRC, as well as through the Australian National Network in Marine Science via UTAS IMAS. We thank the personnel of RV Marion Dufresne, Institut Paul Emile Victor, Institut National des Sciences de l'Univers, and the KEOPS2 voyage leader Bernard Queguiner and KEOPS2 science team for assistance at sea. Peter Jansen (IMOS), Danny McLaughlan (CSIRO) and David Cherry (CSIRO) contributed to preparation of the free-drifting sediment trap arrays. MODIS (NASA) satellite ocean-colour images courtesy of Francesco d'Ovidio (Univ. Paris). The altimeter and colour/temperature products for the Kerguelen area were produced by Ssalto/Duacs and CLS with support from CNES. We thank the two anonymous referees for their comments, which helped improve the manuscript.

Edited by: I. Obernosterer

\section{References}

Alldredge, A.: The carbon, nitrogen and mass content of marine snow as a function of aggregate size, Deep-Sea Res. Pt. I, 45, 529-541, doi:10.1016/S0967-0637(97)00048-4, 1998.

Alldredge, A. L. and Gotschalk, C. C.: Direct observations of the mass flocculation of diatom blooms: characteristics, settling velocities and formation of diatom aggregates, Deep-Sea Res., 36, 159-171, doi:10.1016/0198-0149(89)90131-3, 1989.

Alldredge, A. L. and Jackson, G. A.: Preface: aggregation in marine systems, Deep-Sea Res. Pt. II, 42, 1-7, doi:10.1016/09670645(95)90003-9, 1995.

Alldredge, A. L. and Silver, M. W.: Characteristics, dynamics and significance of marine snow, Prog. Oceanogr., 20, 41-82, doi:10.1016/0079-6611(88)90053-5, 1988.

Armand, L. K., Crosta, X., Queguiner, B., Mosseri, J., and Garcia, N.: Diatoms preserved in surface sediments of the northeastern Kerguelen Plateau, Deep-Sea Res. Pt. II, 55, 677-692, doi:10.1016/j.dsr2.2007.12.032, 2008.

Bishop, J. K. B., Edmond, J. M., Ketten, D. R., Bacon, M. P., and Silker, W. B.: The chemistry, biology, and vertical flux of particulate matter from the upper $400 \mathrm{~m}$ of the equatorial Atlantic Ocean, Deep Sea Research, 24, 511-548, doi:10.1016/01466291(77)90526-4, 1977.

Blain, S., Queguiner, B., Armand, L., Belviso, S., Bombled, B., Bopp, L., Bowie, A., Brunet, C., Brussaard, C., Carlotti, F., Christaki, U., Corbiere, A., Durand, I., Ebersbach, F., Fuda, J. L., Garcia, N., Gerringa, L., Griffiths, B., Guigue, C., Guillerm, C., Jacquet, S., Jeandel, C., Laan, P., Lefevre, D., Lo Monaco, C., Malits, A., Mosseri, J., Obernosterer, I., Park, Y. H., Picheral, M., Pondaven, P., Remenyi, T., Sandroni, V., Sarthou, G., Savoye, N., Scouarnec, L., Souhaut, M., Thuiller, D., Timmermans, K., Trull, T., Uitz, J., van Beek, P., Veldhuis, M., Vincent, D., Viollier, E., Vong, L., and Wagener, T.: Effect of natural iron fertilization on carbon sequestration in the Southern Ocean, Nature, 446, 10701074, doi:10.1038/nature05700, 2007.

Bowie, A. R., Trull, T. W., and Dehairs, F.: Estimating the sensitivity of the subantarctic zone to environmental change: The SAZ-Sense project, Deep-Sea Res. Pt. II, 58, 2051-2058, doi:10.1016/j.dsr2.2011.05.034, 2011.

Bowie, A. R., van der Merwe, P., Quéroué, F., Trull, T., Fourquez, M., Planchon, F., Sarthou, G., Chever, F., Townsend, A. T., Obernosterer, I., Sallée, J.-B., and Blain, S.: Iron budgets for three distinct biogeochemical sites around the Kerguelen archipelago (Southern Ocean) during the natural fertilisation experiment KEOPS-2, Biogeosciences Discuss., 11, 17861-17923, doi:10.5194/bgd-11-17861-2014, 2014.

Boyd, P. W., Watson, A. J., Law, C. S., Abraham, E. R., Trull, T., Murdoch, R., Bakker, D. C. E., Bowie, A. R., Buesseler, K. O., and Chang, H.: A mesoscale phytoplankton bloom in the polar Southern Ocean stimulated by iron fertilization, Nature, 407, 695-702, doi:10.1038/35037500, 2000.

Brinton, E.: Vertical migration and avoidance capability of euphausiids in the California Current, Limnol. Oceanogr., 12, 451483, doi:10.4319/lo.1967.12.3.0451, 1967.

Buesseler, K. O.: The decoupling of production and particulate export in the surface ocean, Global Biogeochem. Cy., 12, 297-310, doi:10.1029/97GB03366, 1998.

Buonassissi, C. and Dierssen, H.: A regional comparison of particle size distributions and the power law approximation in oceanic 
and estuarine surface waters, J. Geophys. Res., 115, C10028, doi:10.1029/2010JC006256, 2010.

Burd, A. B. and Jackson, G. A.: Particle aggregation, Annual Review of Marine Science, 1, 65-90, doi:10.1146/annurev.marine.010908.163904, 2009.

Carlotti, F., Jouandet, M.-P., Nowaczyk, A., Harmelin-Vivien, M., Lefèvre, D., Guillou, G., Zhu, Y., and Zhou, M.: Mesozooplankton structure and functioning during the onset of the Kerguelen phytoplankton bloom during the Keops2 survey, Biogeosciences Discuss., 12, 2381-2427, doi:10.5194/bgd-12-2381-2015, 2015.

Carroll, M. L., Miquel, J.-C., and Fowler, S. W.: Seasonal patterns and depth-specific trends of zooplankton fecal pellet fluxes in the Northwestern Mediterranean Sea, Deep-Sea Res. Pt. I, 45, 1303 1318, doi:10.1016/S0967-0637(98)00013-2, 1998.

Cavagna, A.-J., Dehairs, F., Bouillon, S., Woule-Ebongué, V., Planchon, F., Delille, B., and Bouloubassi, I.: Water column distribution and carbon isotopic signal of cholesterol, brassicasterol and particulate organic carbon in the Atlantic sector of the Southern Ocean, Biogeosciences, 10, 2787-2801, doi:10.5194/bg-102787-2013, 2013.

Cavagna, A. J., Fripiat, F., Elskens, M., Dehairs, F., Mangion, P., Chirurgien, L., Closset, I., Lasbleiz, M., Flores-Leiva, L., Cardinal, D., Leblanc, K., Fernandez, C., Lefèvre, D., Oriol, L., Blain, S., and Quéguiner, B.: Biological productivity regime and associated $\mathrm{N}$ cycling in the vicinity of Kerguelen Island area, Southern Ocean, Biogeosciences Discuss., 11, 18073-18104, doi:10.5194/bgd-11-18073-2014, 2014.

Christaki, U., Lefèvre, D., Georges, C., Colombet, J., Catala, P., Courties, C., Sime-Ngando, T., Blain, S., and Obernosterer, I.: Microbial food web dynamics during spring phytoplankton blooms in the naturally iron-fertilized Kerguelen area (Southern Ocean), Biogeosciences, 11, 6739-6753, doi:10.5194/bg-116739-2014, 2014.

Coale, K. H., Johnson, K. S., Chavez, F. P., Buesseler, K. O., Barber, R. T., Brzezinski, M. A., Cochlan, W. P., Millero, F. J., Falkowski, P. G., Bauer, J. E., Wanninkhof, R. H., Kudela, R. M., Altabet, M. A., Hales, B. E., Takahashi, T., Landry, M. R., Bidigare, R. R., Wang, X., Chase, Z., Strutton, P. G., Friederich, G. E., Gorbunov, M. Y., Lance, V. P., Hilting, A. K., Hiscock, M. R., Demarest, M., Hiscock, W. T., Sullivan, K. F., Tanner, S. J., Gordon, R. M., Hunter, C. N., Elrod, V. A., Fitzwater, S. E., Jones, J. L., Tozzi, S., Koblizek, M., Roberts, A. E., Herndon, J., Brewster, J., Ladizinsky, N., Smith, G., Cooper, D., Timothy, D., Brown, S. L., Selph, K. E., Sheridan, C. C., Twining, B. S., and Johnson, Z. I.: Southern Ocean iron enrichment experiment: carbon cycling in high- and low-Si waters, Science, 304, 408-414, doi:10.1126/science.1089778, 2004.

Crocker, K. M. and Passow, U.: Differential aggregation of diatoms, Mar. Ecol.-Prog. Ser., 117, 249-257, doi:10.3354/meps117249, 1995.

de Baar, H. J. W., de Jong, J. T. M., Bakker, D. C. E., Loscher, B. M., Veth, C., Bathmann, U., and Smetacek, V.: Importance of iron for plankton blooms and carbon dioxide drawdown in the Southern Ocean, Nature, 373, 412-415, doi:10.1038/373412a0, 1995.

De La Rocha, C. and Passow, U.: Factors influencing the sinking of POC and the efficiency of the biological carbon pump, Deep-Sea Res. Pt. II, 54, 639-658, doi:10.1016/j.dsr2.2007.01.004, 2007.

d'Ovidio, F., Della Penna, A., Trull, T. W., Nencioli, F., Pujol, I., Rio, M. H., Park, Y.-H., Cotté, C., Zhou, M., and
Blain, S.: The biogeochemical structuring role of horizontal stirring: Lagrangian perspectives on iron delivery downstream of the Kerguelen plateau, Biogeosciences Discuss., 12, 779—814, doi:10.5194/bgd-12-779-2015, 2015.

Ebersbach, F. and Trull, T. W.: Sinking particle properties from polyacrylamide gels during the KErguelen Ocean and Plateau compared study (KEOPS): Zooplankton control of carbon export in an area of persistent natural iron inputs in the Southern Ocean, Limnol. Oceanogr., 53, 212-224, doi:10.4319/lo.2008.53.1.0212, 2008.

Ebersbach, F., Trull, T. W., Davies, D. M., and Bray, S. G.: Controls on mesopelagic particle fluxes in the Sub-Antarctic and Polar Frontal Zones in the Southern Ocean south of Australia in summer - Perspectives from free-drifting sediment traps, DeepSea Res. Pt. II, 58, 2260-2276, doi:10.1016/j.dsr2.2011.05.025, 2011.

Eppley, R. W. and Peterson, B. J.: Particulate organic matter flux and planktonic new production in the deep ocean, Nature, 282, 677-680, doi:10.1038/282677a0, 1979.

Espinasse, B., Zhou, M., Zhu, Y., Hazen, E., Friedlaender, A., Nowacek, D., Chu, D., and Carlotti, F.: Austral fall-winter transition of mesozooplankton assemblages and krill aggregations in an embayment west of the Antarctic Peninsula, Mar. Ecol.-Prog. Ser., 452, 63-80, 2012.

Fleminger, A. and Clutter, R. I.: Avoidance of towed nets by zooplankton, Limnol. Oceanogr., 10, 96-104, doi:10.4319/lo.1965.10.1.0096, 1965.

Fowler, S. W. and Knauer, G. A.: Role of large particles in the transport of elements and organic compounds through the oceanic water column, Prog. Oceanogr., 16, 147-194, doi:10.1016/00796611(86)90032-7, 1986.

Fowler, S. W. and Small, L. F.: Sinking rates of euphausiid fecal pellets, Limnol. Oceanogr., 17, 293-296, doi:10.4319/lo.1972.17.2.0293, 1972.

Gauld, D. T.: A peritrophic membrane in calanoid copepods, Nature, 179, 325-326, doi:10.1038/179325a0, 1957.

Giering, S. L. C., Sanders, R., Lampitt, R. S., Anderson, T. R., Tamburini, C., Boutrif, M., Zubkov, M. V., Marsay, C. M., Henson, S. A., Saw, K., Cook, K., and Mayor, D. J.: Reconciliation of the carbon budget in the ocean's twilight zone, Nature, 507, 480 483, doi:10.1038/nature13123, 2014.

González, H. E. and Smetacek, V.: The possible role of the cyclopoid copepod Oithona in retarding vertical flux of zooplankton faecal material, Mar. Ecol.-Prog. Ser., 113, 233-246, doi:10.3354/meps113233, 1994.

González, H., González, S., and Brummer, G.: Short-term sedimentation pattern of zooplankton, faeces and microplankton at a permanent station in the Bjørnafjorden (Norway) during April-May 1992, Mar. Ecol.-Prog. Ser., 105, 31-45, doi:10.3354/meps105031, 1994.

González, H. E., Ortiz, V. C., and Sobarzo, M.: The role of faecal material in the particulate organic carbon flux in the northern Humboldt Current, Chile $\left(23^{\circ} \mathrm{S}\right)$, before and during the 1997-1998 El Niño, J. Plankton Res., 22, 499-529, doi:10.1093/plankt/22.3.499, 2000.

González, H. E., Daneri, G., Iriarte, J. L., Yannicelli, B., Menschel, E., Barría, C., Pantoja, S., and Lizárraga, L.: Carbon fluxes within the epipelagic zone of the Humboldt Current System off Chile: The significance of euphausiids and diatoms as key functional 
groups for the biological pump, Prog. Oceanogr., 83, 217-227, doi:10.1016/j.pocean.2009.07.036, 2009.

Guidi, L., Stemmann, L., Jackson, G. A., Ibanez, F., Claustre, H., Legendre, L., Picheral, M., and Gorsky, G.: Effects of phytoplankton community on production, size and export of large aggregates: a world-ocean analysis, Limnol. Oceanogr., 54, 19511963, doi:10.4319/1o.2009.54.6.1951, 2009.

Hargraves, P. E. and French, F.: Diatom resting spores: Significance and strategies, in: Survival Strategies of the Algae, edited by: Fryxell, G., Cambridge University Press, New York, 49-68, 1983.

Iversen, M. H. and Poulsen, L.: Coprorhexy, coprophagy, and coprochaly in the copepods Calanus helgolandicus, Pseudocalanus elongatus, and Oithona similis, Mar. Ecol.-Prog. Ser., 350, 7989, doi:10.3354/meps07095, 2007.

Jackson, G. A.: A model of the formation of marine algal flocs by physical coagulation processes, Deep-Sea Res. Pt. I, 37, 11971211, doi:10.1016/0198-0149(90)90038-W, 1990.

Jackson, G. A.: Coagulation theory and models of oceanic plankton aggregation, in: Flocculation in Natural and Engineered Environmental Systems, CRC Press, 271-292, 2005.

Jackson, G. A., Maffione, R., Costello, D. K., Alldredge, A. L., Logan, B. E., and Dam, H. G.: Particle size spectra between $1 \mu \mathrm{m}$ and $1 \mathrm{~cm}$ at Monterey Bay determined using multiple instruments, Deep-Sea Res. Pt. I, 44, 1739-1767, doi:10.1016/S09670637(97)00029-0, 1997.

Jackson, G. A., Waite, A. M., and Boyd, P. W.: Role of algal aggregation in vertical carbon export during SOIREE and in other low biomass environments, Geophys. Res. Lett., 32, L13607, doi:10.1029/2005g1023180, 2005.

Jacquet, S. H. M., Lam, P. J., Trull, T., and Dehairs, F.: Carbon export production in the subantarctic zone and polar front zone south of Tasmania, Deep-Sea Res. Pt. II, 58, 2277-2292, doi:10.1016/j.dsr2.2011.05.035, 2011.

Jannasch, H. W., Zafiriou, O. C., and Farrington, J. W.: A sequencing sediment trap for time-series studies of fragile particles, Limnol. Oceanogr., 25, 939-943, doi:10.4319/lo.1980.25.5.0939, 1980.

Kuwata, A. and Takahashi, M.: Life-form population responses of a marine planktonic diatom, Chaetoceros pseudocurvisetus, to oligotrophication in regionally upwelled water, Mar. Biol., 107, 503-512, doi:10.1007/BF01313435, 1990.

Lam, P. J. and Bishop, J. K. B.: High biomass, low export regimes in the Southern Ocean, Deep-Sea Res. Pt. II, 54, 601-638, doi:10.1016/j.dsr2.2007.01.013, 2007.

Lam, P. J., Doney, S. C., and Bishop, J. K. B.: The dynamic ocean biological pump: Insights from a global compilation of particulate organic carbon, $\mathrm{CaCO}_{3}$, and opal concentration profiles from the mesopelagic, Global Biogeochem. Cy., 25, GB3009, doi:10.1029/2010GB003868, 2011.

Lampitt, R. S., Noji, T., and Bodungen, B.: What happens to zooplankton faecal pellets? Implications for material flux, Mar. Biol., 104, 15-23, doi:10.1007/BF01313152, 1990.

Lasbleiz, M., Leblanc, K., Blain, S., Ras, J., Cornet-Barthaux, V., Hélias Nunige, S., and Quéguiner, B.: Pigments, elemental composition $(\mathrm{C}, \mathrm{N}, \mathrm{P}, \mathrm{Si})$ and stoichiometry of particulate matter, in the naturally iron fertilized region of Kerguelen in the Southern Ocean, Biogeosciences, 11, 5931-5955, doi:10.5194/bg-115931-2014, 2014.
Laurenceau-Cornec, E. C., Trull, T. W., Davies, D., De La Rocha, C. L., and Blain, S.: Phytoplankton morphology controls on marine snow sinking velocity, Mar. Ecol.-Prog. Ser., 520, 3556, doi:10.3354/meps11116, 2015.

Lefèvre, D., Guigue, C., and Obernosterer, I.: The metabolic balance at two contrasting sites in the Southern Ocean: the ironfertilized Kerguelen area and HNLC waters, Deep-Sea Res. Pt. II, 55, 766-776, doi:10.1016/j.dsr2.2007.12.006, 2008.

Lundsgaard, C.: Use of a high viscosity medium in studies of aggregates, in: Sediment Trap Studies in the Nordic Countries. 3. Proceeding of the Symposium on Seasonal Dynamics of Planktonic Ecosystems and Sedimentation in Coastal Nordic Waters. Finnish Environment Agency, edited by: Floderus, S., Heisakanen, A. S., Oleson, M., and Wassmann, P., Numi Print, Oy, Germany, 141-152, 1995.

Maiti, K., Charette, M. A., Buesseler, K. O., and Kahru, M.: An inverse relationship between production and export efficiency in the Southern Ocean, Geophys. Res. Lett., 40, 1557-1561, doi:10.1002/grl.50219, 2013.

Martens, P.: Faecal pellets, in: Fiches d'identification du zooplancton, edited by: Fraser, J. H., Conseil International pour l'Exploration de la Mer, 162, p. 4, 1978.

Martin, J. H.: Glacial-interglacial $\mathrm{CO}_{2}$ change: the iron hypothesis, Paleoceanography, 5, 1-13, doi:10.1029/PA005i001p00001, 1990.

Martin, J. H., Knauer, G. A., Karl, D. M., and Broenkow, W. W.: VERTEX: carbon cycling in the northeast Pacific, Deep Sea Research Part A. Oceanographic Research Papers, 34, 267-285, doi:10.1016/0198-0149(87)90086-0, 1987.

McCave, I. N.: Size spectra and aggregation of suspended particles in the deep ocean, Deep-Sea Res., 31, 329-352, doi:10.1016/0198-0149(84)90088-8, 1984.

McDonnell, A. M. P. and Buesseler, K. O.: Variability in the average sinking velocity of marine particles, Limnol. Oceanogr., 55, 2085-2096, doi:10.4319/lo.2010.55.5.2085, 2010.

Michaels, A. F. and Silver, M. W.: Primary production, sinking fluxes and the microbial food web, Deep-Sea Res., 35, 473-490, doi:10.1016/0198-0149(88)90126-4, 1988.

Morris, P. J., Sanders, R., Turnewitsch, R., and Thomalla, S.: ${ }^{234}$ Thderived particulate organic carbon export from an island-induced phytoplankton bloom in the Southern Ocean, Deep-Sea Res. Pt. II, 54, 2208-2232, doi:10.1016/j.dsr2.2007.06.002, 2007.

Mosseri, J., Quéguiner, B., Armand, L., and Cornet-Barthaux, V.: Impact of iron on silicon utilization by diatoms in the Southern Ocean: A case study of $\mathrm{Si} / \mathrm{N}$ cycle decoupling in a naturally iron-enriched area, Deep-Sea Res. Pt. II, 55, 801-819, doi:10.1016/j.dsr2.2007.12.003, 2008.

Park, Y.-H., Charriaud, E., Pino, D. R., and Jeandel, C.: Seasonal and interannual variability of the mixed layer properties and steric height at station KERFIX, southwest of Kerguelen, J. Marine Syst., 17, 571-586, doi:10.1016/S0924-7963(98)00065-7, 1998.

Pilskaln, C. H. and Honjo, S.: The fecal pellet fraction of biogeochemical particle fluxes to the deep sea, Global Biogeochem. Cy., 1, 31-48, doi:10.1029/GB001i001p00031, 1987.

Planchon, F., Ballas, D., Cavagna, A.-J., Bowie, A. R., Davies, D., Trull, T. W., Laurenceau-Cornec, E. C., van der Merwe, P., and Dehairs, F.: Carbon export in the naturally iron-fertilized Kerguelen area of the Southern Ocean based on the ${ }^{234} \mathrm{Th}$ approach, 
Biogeosciences Discuss., 11, 15991-16032, doi:10.5194/bgd11-15991-2014, 2014.

Pollard, R., Sanders, R., Lucas, M., and Statham, P.: The Crozet Natural Iron Bloom and Export Experiment (CROZEX), DeepSea Res. Pt. II, 54, 1905-1914, doi:10.1016/j.dsr2.2007.07.023, 2007.

Quéguiner, B.: Iron fertilization and the structure of planktonic communities in high nutrient regions of the Southern Ocean, Deep-Sea Res. Pt. II, 90, 43-54, doi:10.1016/j.dsr2.2012.07.024, 2013.

Riebesell, U., Schloss, I., and Smetacek, V.: Aggregation of algae released from melting sea ice: implications for seeding and sedimentation, Polar Biol., 11, 239-248, doi:10.1007/bf00238457, 1991.

Rynearson, T. A., Richardson, K., Lampitt, R. S., Sieracki, M. E., Poulton, A. J., Lyngsgaard, M. M., and Perry, M. J.: Major contribution of diatom resting spores to vertical flux in the sub-polar North Atlantic, Deep-Sea Res. Pt. I, 82, 60-71, doi:10.1016/j.dsr.2013.07.013, 2013.

Salter, I., Lampitt, R. S., Sanders, R., Poulton, A., Kemp, A. E. S., Boorman, B., Saw, K., and Pearce, R.: Estimating carbon, silica and diatom export from a naturally fertilised phytoplankton bloom in the Southern Ocean using PELAGRA: A novel drifting sediment trap, Deep-Sea Res. Pt. II, 54, 2233-2259, doi:10.1016/j.dsr2.2007.06.008, 2007.

Salter, I., Kemp, A. E. S., Moore, C. M., Lampitt, R. S., Wolff, G. A., and Holtvoeth, J.: Diatom resting spore ecology drives enhanced carbon export from a naturally iron-fertilized bloom in the Southern Ocean, Global Biogeochem. Cy., 26, GB1014, doi:10.1029/2010GB003977, 2012.

Savoye, N., Trull, T. W., Jacquet, S. H. M., Navez, J., and Dehairs, F.: ${ }^{234}$ Th-based export fluxes during a natural iron fertilization experiment in the Southern Ocean (KEOPS), Deep-Sea Res. Pt. II, 55, 841-855, doi:10.1016/j.dsr2.2007.12.036, 2008.

Sigman, D. M. and Boyle, E. A.: Glacial/interglacial variations in atmospheric carbon dioxide, Nature, 407, 859-869, doi:10.1038/35038000, 2000.

Silver, M. W. and Gowing, M. M.: The "Particle" Flux: origins and biological components, Prog. Oceanogr., 26, 75-113, doi:10.1016/0079-6611(91)90007-9, 1991.

Small, L. F., Fowler, S. W., and Ünlü, M. Y.: Sinking rates of natural copepod fecal pellets, Mar. Biol., 51, 233-241, doi:10.1007/BF00386803, 1979.

Smetacek, V., Klaas, C., Strass, V. H., Assmy, P., Montresor, M., Cisewski, B., Savoye, N., Webb, A., d'Ovidio, F., Arrieta, J. M., Bathmann, U., Bellerby, R., Berg, G. M., Croot, P., Gonzalez, S., Henjes, J., Herndl, G. J., Hoffmann, L. J., Leach, H., Losch, M., Mills, M. M., Neill, C., Peeken, I., Rottgers, R., Sachs, O., Sauter, E., Schmidt, M. M., Schwarz, J., Terbruggen, A., and Wolf-Gladrow, D.: Deep carbon export from a Southern Ocean iron-fertilized diatom bloom, Nature, 487, 313-319, doi:10.1038/nature11229, 2012.

Suess, E.: Particulate organic carbon flux in the oceans - surface productivity and oxygen utilization, Nature, 288, 260-263, doi:10.1038/288260a0, 1980.

Suzuki, H., Sasaki, H., and Fukuchi, M.: Loss processes of sinking fecal pellets of zooplankton in the mesopelagic layers of the Antarctic Marginal Ice Zone, J. Oceanogr., 59, 809-818, doi:10.1023/B:JOCE.0000009572.08048.0d, 2003.
Trull, T. W., Bray, S. G., Buesseler, K. O., Lamborg, C. H., Manganini, S., Moy, C., and Valdes, J.: In situ measurement of mesopelagic particle sinking rates and the control of carbon transfer to the ocean interior during the Vertical Flux in the Global Ocean (VERTIGO) voyages in the North Pacific, DeepSea Res. Pt. II, 55, 1684-1695, doi:10.1016/j.dsr2.2008.04.021, 2008.

Trull, T. W., Davies, D. M., Dehairs, F., Cavagna, A.-J., Lasbleiz, M., Laurenceau-Cornec, E. C., d'Ovidio, F., Planchon, F., Leblanc, K., Quéguiner, B., and Blain, S.: Chemometric perspectives on plankton community responses to natural iron fertilization over and downstream of the Kerguelen Plateau in the Southern Ocean, Biogeosciences Discuss., 11, 13841-13903, doi:10.5194/bgd-11-13841-2014, 2014.

Turner, J. T.: Zooplankton fecal pellets, marine snow and sinking phytoplankton blooms, Aquat. Microb. Ecol., 27, 57-102, doi:10.3354/ame027057, 2002.

Urban-Rich, J., Hansell, D. A., and Roman, M. R.: Analysis of copepod fecal pellet carbon using a high temperature combustion method, Mar. Ecol.-Prog. Ser., 171, 199-208, doi:10.3354/meps171199, 1998.

Volk, T. and Hoffert, M. I.: Ocean carbon pumps: Analysis of relative strengths and efficiencies in ocean-driven atmospheric $\mathrm{CO}_{2}$ changes, in: The Carbon Cycle and Atmospheric $\mathrm{CO}_{2}$ : Natural Variations Archean to Present, edited by: Sundquist, E. T. and Broecker, W. S., AGU, Washington, DC, 99-110, 1985.

Waite, A. M. and Nodder, S. D.: The effect of in situ iron addition on the sinking rates and export flux of Southern Ocean diatoms, Deep-Sea Res. Pt. II, 48, 2635-2654, doi:10.1016/S09670645(01)00012-1, 2001.

Wallace, M. I., Cottier, F. R., Brierley, A. S., and Tarling, G. A.: Modelling the influence of copepod behaviour on faecal pellet export at high latitudes, Polar Biol., 36, 579-592, doi:10.1007/s00300-013-1287-7, 2013.

Wassmann, P.: Relationship between primary and export production in the boreal coastal zone of the North Atlantic, Limnol. Oceanogr., 35, 464-471, doi:10.4319/lo.1990.35.2.0464, 1990.

Wassmann, P.: Retention vs. export food chains: processes controlling sinking loss from marine pelagic systems, Hydrobiologia, 363, 29-57, doi:10.1023/A:1003113403096, 1998.

Wassmann, P., Ypma, J. E., and Tselepides, A.: Vertical flux of faecal pellets and microplankton on the shelf of the oligotrophic Cretan Sea (NE Mediterranean Sea), Prog. Oceanogr., 46, 241258, doi:10.1016/S0079-6611(00)00021-5, 2000.

Wiebe, P. H., Burt, K. H., Boyd, S. H., and Morton, A. W.: A multiple opening/closing net and environment sensing system for sampling zooplankton, J. Mar. Res., 34, 313-326, 1976.

Wiebe, P. H., Boyd, S., Davis, B., and Cox, J.: Avoidance of towed nets by the euphausiid Nematoscelis megalops, Fish. B-NOAA, 80, 75-91, 1982.

Yoon, W., Kim, S., and Han, K.: Morphology and sinking velocities of fecal pellets of copepod, molluscan, euphausiid, and salp taxa in the northeastern tropical Atlantic, Mar. Biol., 139, 923-928, doi:10.1007/s002270100630, 2001.

Zhou, M., Zhu, Y., d'Ovidio, F., Park, Y.-H., Durand, I., Kestenare, E., Sanial, V., Van-Beek, P., Queguiner, B., Carlotti, F., and Blain, S.: Surface currents and upwelling in Kerguelen Plateau regions, Biogeosciences Discuss., 11, 6845-6876, doi:10.5194/bgd-116845-2014, 2014. 